



\section{Waterretentie- en doorlatendheidskarakteristieken in met klei verrijkte zandgrond}

Marius Heinen, Gerben Bakker, Frank Gerritsen, Willy de Groot

Dit onderzoek is uitgevoerd door Wageningen Environmental Research en maakt onderdeel uit van het samenwerkingsproject KLIMAP ('Klimaatadaptatie in de praktijk') dat mede gefinancierd wordt door de Topsectoren Agri \& Food en Water \& Maritiem.

Wageningen Environmental Research

Wageningen, januari 2022

Gereviewd door:

G. Bakema, onderzoeker bodem en water (WENR) en R. Bartholomeus (KWR \& WUR)

Akkoord voor publicatie:

M.J.D. Hack-ten Broeke, teamleider van team Bodem, Water en Landgebruik

Rapport 3145

ISSN 1566-7197 
Marius Heinen, Gerben Bakker, Frank Gerritsen, Willy de Groot, 2022. Waterretentie- en

doorlatendheidskarakteristieken in met klei verrijkte zandgrond. Wageningen, Wageningen Environmental

Research, Rapport 3145. 38 blz.; 11 fig.; 6 tab.; 13 ref.

Waterretentie en doorlatendheid van een bodem zijn afhankelijk van de textuur en structuur. Wanneer klei door de bovenlaag van een zandgrond wordt vermengd, veranderen de textuur en structuur van deze bovengrond. In deze studie zijn de waterretentie- en doorlatendheidskarakteristieken van met klei verrijkte zandmonsters vergeleken met die van zand.

Water retention and hydraulic conductivity of soils are dependent on texture and structure. In case clay is mixed in a sandy top soil this will change its texture and structure. In this study the water retention and hydraulic conductivity characteristics are determined for samples with clay mixed in sand and compared to those for sand.

Trefwoorden: doorlatendheidskarakteristiek, kritieke flux, SWAP-WOFOST, waterbeschikbaarheid, waterretentiekarakteristiek

Dit rapport is gratis te downloaden van https://doi.org/10.18174/561450 of op www.wur.nl/environmentalresearch (ga naar 'Wageningen Environmental Research' in de grijze balk onderaan). Wageningen Environmental Research verstrekt geen gedrukte exemplaren van rapporten.

(C) 2022 Wageningen Environmental Research (instituut binnen de rechtspersoon Stichting Wageningen Research), Postbus 47, 6700 AA Wageningen, T 03174807 00, www.wur.nl/environmental-research. Wageningen Environmental Research is onderdeel van Wageningen University \& Research.

- Overname, verveelvoudiging of openbaarmaking van deze uitgave is toegestaan mits met duidelijke bronvermelding.

- Overname, verveelvoudiging of openbaarmaking is niet toegestaan voor commerciële doeleinden en/of geldelijk gewin.

- Overname, verveelvoudiging of openbaarmaking is niet toegestaan voor die gedeelten van deze uitgave waarvan duidelijk is dat de auteursrechten liggen bij derden en/of zijn voorbehouden.

Wageningen Environmental Research aanvaardt geen aansprakelijkheid voor eventuele schade voortvloeiend uit het gebruik van de resultaten van dit onderzoek of de toepassing van de adviezen.

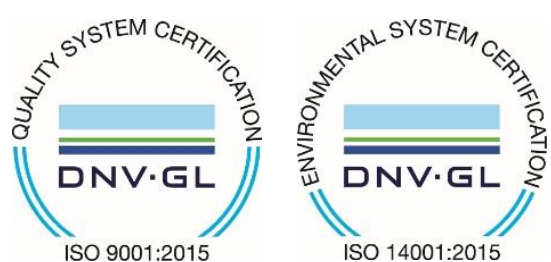

ISO $9001: 2015$
Wageningen Environmental Research werkt sinds 2003 met een ISO 9001 gecertificeerd kwaliteitsmanagementsysteem.

In 2006 heeft Wageningen Environmental Research een milieuzorgsysteem geïmplementeerd, gecertificeerd volgens de norm ISO 14001.

Wageningen Environmental Research geeft via ISO 26000 invulling aan haar maatschappelijke verantwoordelijkheid.

Wageningen Environmental Research Rapport 3145 | ISSN 1566-7197

Foto omslag: Frank Gerritsen (WENR) 


\section{Inhoud}

Verantwoording

Woord vooraf

Samenvatting

$2.1 \quad$ Locatie

2.2 Profielbeschrijving

2.3 Grondmonsters

2.4 Waterretentie- en doorlatendheidskarakteristieken

2.5 Waterbeschikbaarheid en kritieke flux

2.6 Simulatie

3

$\begin{array}{lr}\text { Resultaten en discussie } & 19\end{array}$

$\begin{array}{llr}3.1 & \text { Textuur } & 19\end{array}$

3.2 Verdampingsmethode: Mualem-Van Genuchten- parameters 20

\begin{tabular}{ll}
3.3 & Waterbeschikbaarheid en kritieke flux \\
\hline
\end{tabular}

$\begin{array}{ll}3.4 & \text { Aanvullende metingen } \\ 3.5 & 25\end{array}$

$\begin{array}{lll}3.5 & \text { Simulaties } & 26\end{array}$

$\begin{array}{llr}4 & \text { Bevindingen } & 28\end{array}$

Literatuur
29

Bijlage 1 Quickscan literatuur 30

Bijlage 2 Figuren dataverwerking verdampingsmethode 31

Bijlage $3 \quad$ Foto's monsters doorlatendheidsmetingen 36 
$\longrightarrow$ 


\section{Verantwoording}

Rapport: 3145

Projectnummer: 5200045730

Wageningen Environmental Research (WENR) hecht grote waarde aan de kwaliteit van zijn eindproducten. Een review van de rapporten op wetenschappelijke kwaliteit door een referent maakt standaard onderdeel uit van ons kwaliteitsbeleid.

Akkoord referent die het rapport heeft beoordeeld,

functie: $\quad$ Onderzoeker bodem en water (WENR)

naam: G. Bakema

datum: $\quad 19-11-2021$

Akkoord referent die het rapport heeft beoordeeld,

functie: $\quad$ Chief Science Officer en Principal Scientist van team Ecohydrologie water (KWR \& WUR)

naam: $\quad$ R. Bartholomeus

datum: $\quad 17-12-2021$

Akkoord teamleider voor de inhoud,

naam: M.J.D. Hack-ten Broeke

datum: $\quad 08-11-2021$ 


\section{Woord vooraf}

In het project KLIMAP ('Klimaatadaptatie in de Praktijk'), dat medegefinancierd wordt door de Topsectoren Agri \& Food en Water \& Maritiem, onderzoeken 24 partijen, waaronder regionale overheden, kennisinstellingen en bedrijven, hoe het water- en bodemsysteem op zandgronden klimaatadaptief kan worden ingericht voor landbouw en natuur. Op verschillende locaties (proefgebieden) worden diverse maatregelen in de praktijk toegepast en onderzocht (https://www.klimap.nl). Op proefbedrijf De Marke (Hengelo, Gld) is vanuit KLIMAP aansluiting gezocht bij een aldaar lopend project waarin wordt onderzocht of klei toegevoegd aan zandgrond de bodemkwaliteit verbetert op een manier die zowel de landbouwkundige doelen als de kwaliteitsdoelen voor klimaat, lucht en water dient. In dit rapport wordt een deelonderzoek beschreven, waarbij aanvullende metingen zijn uitgevoerd om de waterretentie- en doorlatendheidskarakteristieken te bepalen in met klei verrijkte zandgrond.

De volgende partners zijn betrokken in de financiering en uitvoering van het samenwerkingsproject KLIMAP: Waterschap Aa en Maas, Waterschap Vallei en Veluwe, Waterschap De Dommel, Waterschap Brabantse Delta, Waterschap Limburg, Waterschap Vechtstromen, Waterschap Rijn en IJssel, Provincie Noord-Brabant, Provincie Gelderland, Provincie Limburg, STOWA, LLTB, KWR Water Research Institute, Deltares, Wageningen Environmental Research, Wageningen Livestock Research, Wageningen Universiteit, Radboud Universiteit, Louis Bolk instituut, Van den Borne projecten, KnowH2O, Kuipers Electronic Engineering, Barth Drainage.

Dank aan Luuk Gollenbeek (WLR), Zwier van der Vegte en Gerjan Hilhorst (proefboerderij De Marke) voor toestemming voor bemonstering in het klei-in-zand maisperceel. Dank aan Ruud van Uffelen (Provincie Gelderland) voor regelen van toestemming voor de bemonstering kleilocaties in Aerdt en Tricht. Dank aan Falentijn Assinck voor hulp bij bemonstering. 


\section{Samenvatting}

Op proefbedrijf De Marke en bij boerenbedrijven in hun nabije omgeving worden sinds 2019 proeven uitgevoerd met het aanbrengen van (organisch-rijke) klei. De doelstelling is om na te gaan of de lokale schrale zandgronden hierdoor een betere vocht- en mineralen-bergend vermogen verkrijgen. Vanuit onderzoeksproject KLIMAP is een aanvullend deelonderzoek uitgevoerd waarbij de waterretentie- en doorlatendheidskarakteristieken zijn gemeten in plots waarin 5 of $10 \mathrm{~cm}$ lichte of zware klei was toegediend; deze karakteristieken zijn vergeleken met die van het zand (referentie) en van de locaties waar de klei vandaan kwam. Hierbij is onder meer gekeken naar de waterbeschikbaarheid en de kritieke flux. De waterbeschikbaarheid volgt uit de waterretentiekarakteristiek als het verschil in watergehalte bij veldcapaciteit en bij verwelkingspunt. De kritieke flux volgt uit de doorlatendheidskarakteristiek en kan gezien worden als een capaciteit om water capillair aan te voeren vanuit het grondwater. Omdat deze twee kengetallen statisch dan wel stationair zijn, geven ze mogelijk onvoldoende informatie hoe dat doorwerkt in de praktijk. Daarom zijn aanvullend simulaties uitgevoerd met SWAP-WOFOST, waarbij de lokaal gemeten karakteristieken zijn gebruikt. Hierbij is gekeken naar de variatie in drogestofproducties voor mais voor een klimaatreeks van 1975-2020.

Uit de organischestof- en textuurbepalingen is gebleken dat het organischestofgehalte van het zand een fractie verandert bij toediening van organisch-rijke klei. Het lutumgehalte van de bovengrond neemt duidelijk toe als gevolg van de kleitoevoeging. Bij de toevoeging van $10 \mathrm{~cm}$ lichte of zware klei verandert de textuurklasse-indeling voor de A-horizont en is er sprake van een lichte zavel.

De waterretentie- en doorlatendheidskarakteristieken van de zandbovengrond veranderen van vorm door de toevoegingen van klei. Dit is met name duidelijk te zien voor de waterretentiekarakteristiek nabij de uiteinden; deze verschuiven ten opzichte van die van zand in de richting van de karakteristieken van de lichte dan wel zware klei. De waterbeschikbaarheid die volgt uit het middendeel van de waterretentiekarakteristiek, verandert niet of nauwelijks; voor de situatie met $10 \mathrm{~cm}$ lichte klei wordt een iets geringere waterbeschikbaarheid berekend. Op basis van de verkregen doorlatendheidskarakteristieken volgt dat de kritieke flux, uitgezonderd voor de situatie met $10 \mathrm{~cm}$ zware klei, toeneemt ten opzichte van de kritieke flux van het oorspronkelijke zand.

Simulaties van de drogestofopbrengst van mais voor de jaren 1975-2020 laten zien dat er kleine verschillen zijn voor de klei-in-zand profielen ten opzichte van de zand-uitgangssituatie. Gemiddeld over alle jaren zijn deze iets hoger. Dat komt overeen met de in het veld gemeten opbrengsten voor 2019 en 2020 waarin iets hogere, maar niet-significante verschillende opbrengsten werden gemeten.

In het perceel waar de monsters waren genomen, was de klei niet goed homogeen vermengd met het zand; er was veelvuldig sprake van grote brokken klei. Zeer waarschijnlijk was de klei te nat ten tijde van aanwending. Wanneer een betere menging in de praktijk mogelijk is, dan is het mogelijk dat iets andere waterretentie- en doorlatendheidskarakteristieken worden verkregen dan die in dit rapport zijn gerapporteerd. Als alternatief zouden deze karakteristieken ook bepaald kunnen worden in (handmatig) perfect gemengde monsters; dit geeft dan een beeld wat er idealiter bereikt kan worden. 


\section{$1 \quad$ Inleiding}

Op proefboerderij De Marke (Hengelo, Gld) wordt in proeven onderzocht wat het effect is van het aanbrengen van lichte en zware klei in de zandige bovengrond van een mais- en grasperceel (2019-2021). Dat onderzoek maakt onderdeel uit van een gezamenlijk initiatief van de Provincie Gelderland, Royal Haskoning DHV en proefboerderij De Marke van Wageningen UR (in samenwerking met LTO Noord, Waterschap Rijn en IJssel, Vitens, Deltaplan Agrarisch Waterbeheer (DAW), Zoetwater Oost-Nederland $(Z O N)$ ). Een van de onderzoeksvragen betreft de invloed van klei-in-zand op de waterhuishouding, zoals het watervasthoudend vermogen en de doorlatendheid. Voor meer details over dit onderzoeksprogramma wordt verwezen naar https://demarke.eu/klei-zandgrond-gras/.

Uit een quickscan in de literatuur blijkt dat de aandacht voor mengen van klein in zand zich vooral gericht heeft op geconditioneerde (laboratorium) situaties (zie Bijlage 1). Hieruit blijkt dat in monsters waarin klei met zand is gemengd, de waterretentie en waterbeschikbaarheid zijn veranderd. Er worden echter geen resultaten beschreven voor situaties waarbij onder praktijkomstandigheden klei door de zandbovengrond is gemengd.

Vanuit onderzoekprogramma KLIMAP (https://www.klimap.nl/) wordt bijgedragen aan de bovengenoemde onderzoeksvraag. Hiertoe zijn in een maisperceel ongestoorde bodemmonsters genomen in plots zonder kleitoevoeging (de natuurlijk aanwezige zandgrond) en in plots waar in de bovenlaag $(0-30 \mathrm{~cm}) 5$ of $10 \mathrm{~cm}$ lichte of zware klei (alle combinaties) is vermengd. Van deze monsters zijn in het bodemfysisch laboratorium van WENR onder meer de waterretentie- en doorlatendheidskarakteristieken bepaald.

Het doel (of hoofdvraag) van dit deelonderzoek is om na te gaan of en in welke mate de toevoeging van klei aan zand (in de A-horizont) de vorm van de waterretentie- en doorlatendheidskarakteristiek verandert. Vervolgens is nagegaan of deze veranderingen van invloed zijn op: i) de beschikbare hoeveelheid water in de eerste bodemlaag, en ii) de met SWAP-WOFOST gesimuleerde gewasproductie voor mais.

In hoofdstuk 2 worden een paar studies uit de internationale literatuur benoemd waarin wordt gerapporteerd over het effect van mengen van klei en zand op het watervasthoudend vermogen. Hoofdstuk 3 beschrijft de materialen en methoden. De resultaten en de discussie zijn beschreven in hoofdstuk 4 . Ten slotte zijn in hoofdstuk 5 de bevindingen samengevat. 


\section{Materiaal en methode}

\section{$2.1 \quad$ Locatie}

Het maisperceel waar de klei-in-zand proef wordt uitgevoerd is gelegen in perceel K1 van proefboerderij De Marke. De locatie van de proefplots is aangegeven met de rode rechthoek in Figuur 2.1 en de indeling van de proef is nader aangeduid in Figuur 2.2. Voor veldjes $1 \mathrm{t} / \mathrm{m} 5$ zijn bodemprofielbeschrijvingen gemaakt en hierin zijn de ongestoorde bodemmonsters genomen; in veld 20 is ter controle van de homogeniteit eveneens een bodemprofielbeschrijving gemaakt.

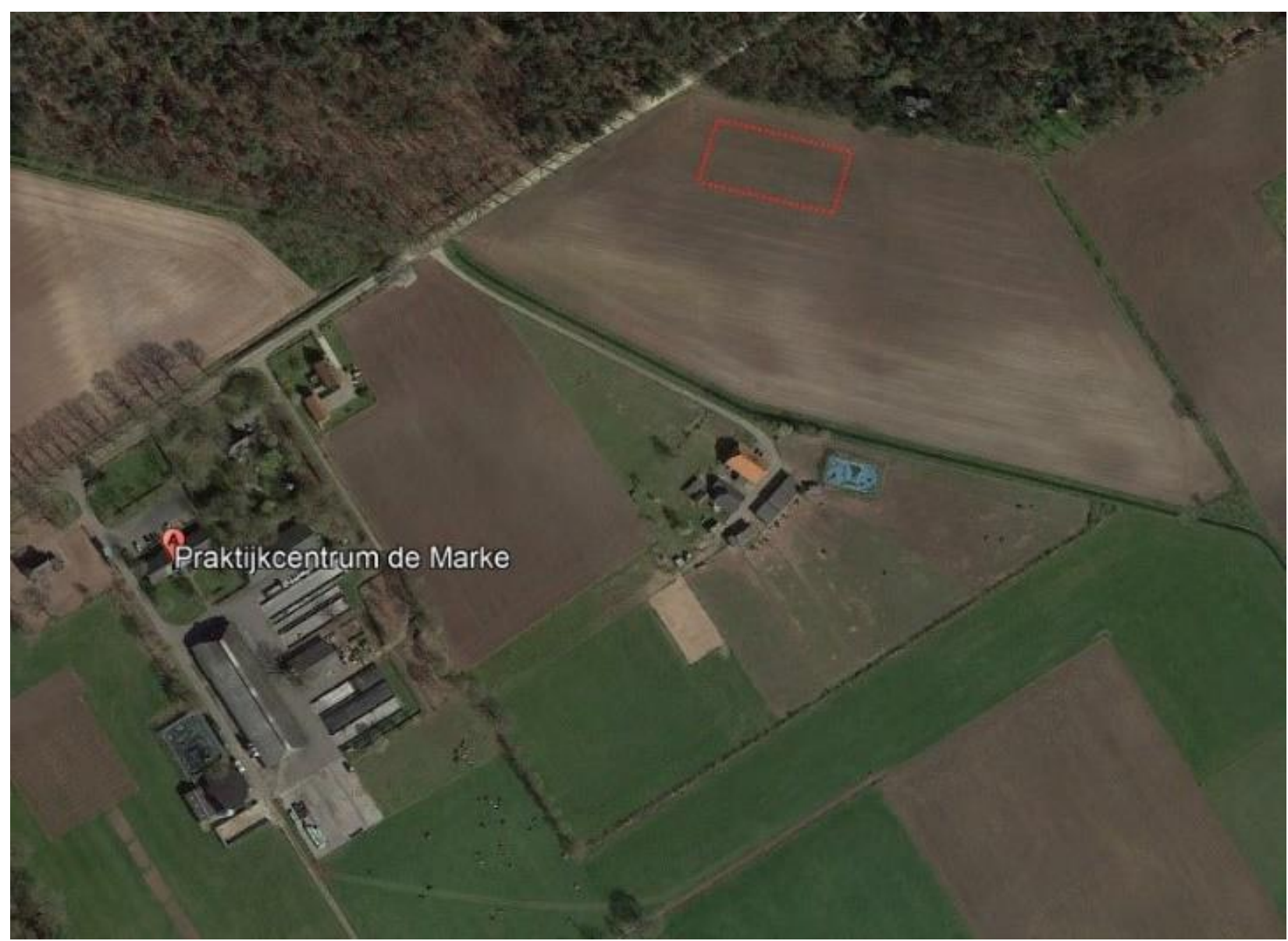

Figuur 2.1 Ligging van de klei-in-zand proef in maisperceel K1 (rode rechthoek) op proefboerderij De Marke.

\subsection{Profielbeschrijving}

Het bodemprofiel van perceel K1 van De Marke valt volgens de Nederlandse bodemkaart (1:50.000) in categorie veldpodzolgronden (leemarm en zwak lemig fijn zand, Hn21) en behoort tot BOFEK2020-eenheid 3015: zwak lemige zandgronden, Hn21 (voornamelijk grasland). BOFEK2020-eenheid 3015 heeft een standaardprofiel, bestaande uit 0-25 cm B2, 25-40 cm 02, 40-60 cm O2 en 60-120 cm O1 (Heinen et al., 2021). Omdat perceel $\mathrm{K} 1$ gebruikt wordt als akkerland, is hier de A-horizont wat dikker $(25-30 \mathrm{~cm})$. Op basis van de veldschatting van het leemgehalte zijn de lagen $30-70 \mathrm{~cm}$ en $70-180 \mathrm{~cm}$ zwak lemig (O2) en de diepe ondergrond $(180-200 \mathrm{~cm}$ ) is sterk lemig (O3) (Tabel 2.1). 
Op basis van de veldschattingen van het lutumgehalte van de bovengronden van de percelen waar de lichte klei (Aerdt, Gld) en de zware klei (Tricht, Gld) vandaan kwamen, betreft het respectievelijk (matig) zware zavel en lichte op matig zware klei. De lichte en zware klei worden in het vervolg respectievelijk afgekort tot Ik en zk.

Voor de profielbeschrijvingen van de klei-in-zandplots werd - uitgezonderd de plot met $10 \mathrm{~cm}$ zk kleibijmenging aangetroffen in de aangeboorde bovengrond. Omdat de menging van de klei in het zand niet uniform heeft plaatsgevonden (zie Figuur 2.3), is deze laag gesplitst beschreven (Tabel 2.1). Tabel 2.2 geeft nog wat aanvullende kenmerken van de locatie.

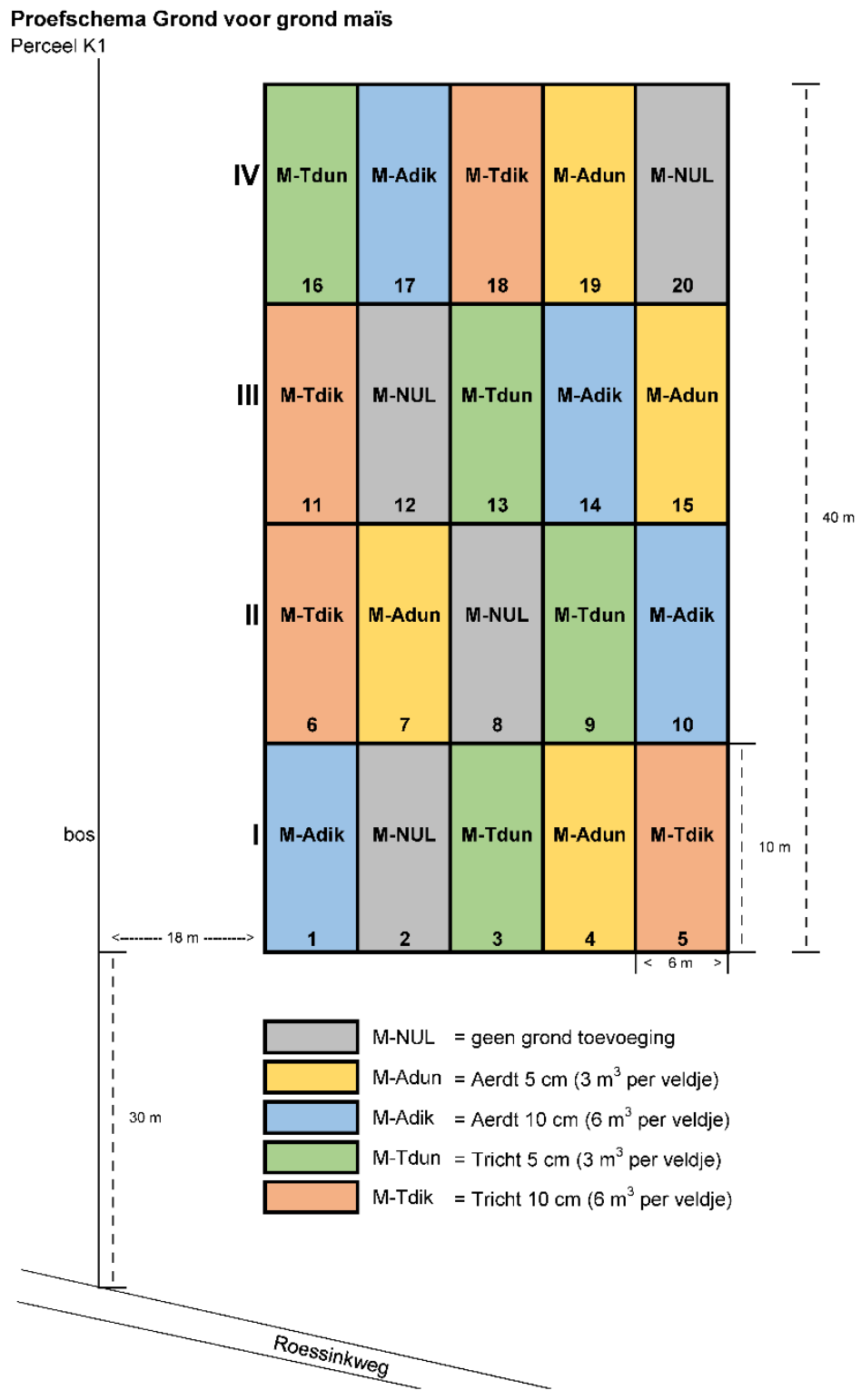

Figuur 2.2 Ligging van de proefplots in perceel K1. 
Tabel 2.1 Bodemprofielbeschrijvingen per bodemlaag ( $\mathrm{cm}-\mathrm{mv}$ ) van de vijf behandelingen (zand in duplo: plots 2 en 20, zie Figuur 2.2) en de twee locaties waar de lichte en zware klei vandaan komen, inclusief veldschattingen van organischestofgehalte (OS), lutum- (Lu) en leemgehaltes (Le), de mediaan zandfractie (M50), kalk en mate van rijping van de klei (Rijp).

\begin{tabular}{|c|c|c|c|c|c|c|c|c|c|c|c|}
\hline Plot & Laag & $\begin{array}{l}\text { Hor. } \\
\text { code }\end{array}$ & $\begin{array}{l}\text { Meng. } \\
\text { verh. }\end{array}$ & $\begin{array}{l}\text { OS } \\
(\%)\end{array}$ & $\begin{array}{l}\text { Lu } \\
(\%)\end{array}$ & $\begin{array}{l}\text { Le } \\
\text { (\%) }\end{array}$ & $\begin{array}{l}\text { M50 } \\
(\mu \mathrm{m})\end{array}$ & $\begin{array}{l}\text { Kalk } \\
(\%)\end{array}$ & Rijp & $\begin{array}{l}\text { Geo } \\
\text { code }\end{array}$ & Opm. \\
\hline \multirow[t]{5}{*}{ Zand (plot 2) } & $0-30$ & $1 \mathrm{Ap}$ & 0 & 4 & 2 & 17 & 170 & 1 & 0 & 692 & \\
\hline & $30-70$ & $1 \mathrm{BC}$ & 0 & 0.7 & 1 & 17 & 155 & 1 & 0 & 411 & 1 \\
\hline & $70-180$ & $1 \mathrm{Cg}$ & 0 & 0.1 & 1 & 12 & 170 & 1 & 0 & 411 & 2 \\
\hline & $180-200$ & $2 \mathrm{Cg}$ & 0 & 0.1 & 3 & 28 & 140 & 1 & 0 & 412 & \\
\hline & $200-220$ & $2 \mathrm{Cr}$ & 0 & 0.1 & 3 & 28 & 140 & 1 & 0 & 412 & 3 \\
\hline \multirow[t]{7}{*}{ Zand (plot 20) } & $0-30$ & $1 \mathrm{Ap}$ & 0 & 4 & 2 & 17 & 170 & 1 & 0 & 692 & \\
\hline & $30-50$ & $1 \mathrm{Bhsc}$ & 0 & 1 & 1 & 14 & 160 & 1 & 0 & 411 & 4 \\
\hline & $50-70$ & $1 \mathrm{Cu} 1$ & 0 & 0.3 & 1 & 14 & 160 & 1 & 0 & 411 & \\
\hline & $70-110$ & $1 \mathrm{Cgc}$ & 0 & 0.1 & 1 & 10 & 180 & 1 & 0 & 413 & 5 \\
\hline & $110-155$ & $1 \mathrm{Cu} 2$ & 0 & 0.1 & 1 & 8 & 170 & 1 & 0 & 413 & \\
\hline & $155-180$ & 2Cer1 & 0 & 0.1 & 1 & 16 & 150 & 1 & 0 & 412 & \\
\hline & $180-200$ & 2Cer2 & 0 & 0.1 & 1 & 20 & 150 & 1 & 0 & 412 & \\
\hline \multirow[t]{4}{*}{ Lichte klei, Ik } & $0-15^{\#}$ & $1 \mathrm{Ah}$ & 0 & 2 & 18 & 0 & 0 & 3 & 5 & 321 & 7 \\
\hline & $15-90$ & $2 \mathrm{Cg}$ & 0 & 0.2 & 5 & 20 & 300 & 3 & 5 & 321 & 8 \\
\hline & $90-130$ & $3 \mathrm{ACg}$ & 0 & 4 & 26 & 45 & 0 & 3 & 5 & 321 & 9 \\
\hline & $130-160$ & $4 \mathrm{Cer}$ & 0 & 3 & 4 & 15 & 300 & 3 & 5 & 321 & \\
\hline \multirow[t]{7}{*}{ Zware klei, zk } & $0-25$ & 1Ahg & 0 & 6 & 26 & 0 & 0 & 1 & 5 & 321 & \\
\hline & $25-35$ & $1 \mathrm{ACg}$ & 0 & 4 & 36 & 0 & 0 & 1 & 5 & 321 & \\
\hline & $35-60$ & $1 \mathrm{Cg} 1$ & 0 & 2 & 52 & 0 & 0 & 1 & 5 & 321 & \\
\hline & $60-70$ & $1 \mathrm{Cg} 2$ & 0 & 10 & 52 & 0 & 0 & 1 & 5 & 321 & 6 \\
\hline & $70-100$ & $2 \mathrm{Cg} 1$ & 0 & 0.5 & 20 & 0 & 0 & 3 & 5 & 321 & \\
\hline & $100-140$ & $2 \mathrm{Cg} 2$ & 0 & 0.1 & 14 & 0 & 0 & 3 & 5 & 321 & \\
\hline & $140-150$ & $2 \mathrm{Cer}$ & 0 & 1 & 20 & 0 & 0 & 3 & 5 & 321 & \\
\hline \multirow[t]{6}{*}{ Zand + $5 \mathrm{lk}$} & $0-25$ & $1 \mathrm{Ap} /$ & 80 & 4 & 2 & 16 & 180 & 1 & 0 & 692 & \\
\hline & $0-25$ & $2 \mathrm{Cg} /$ & 20 & 0.1 & 20 & 0 & 0 & 3 & 5 & 321 & \\
\hline & $25-60$ & $2 B C$ & 0 & 0.7 & 1 & 16 & 160 & 1 & 0 & 411 & 14 \\
\hline & $60-110$ & $2 \mathrm{Cgc}$ & 0 & 0.1 & 1 & 12 & 180 & 1 & 0 & 413 & 15 \\
\hline & $110-190$ & $2 \mathrm{Cu}$ & 0 & 0.1 & 1 & 12 & 160 & 1 & 0 & 413 & \\
\hline & $190-200$ & $3 \mathrm{Cg}$ & 0 & 0.1 & 3 & 26 & 140 & 1 & 0 & 412 & \\
\hline \multirow[t]{7}{*}{ Zand + $5 \mathrm{zk}$} & $0-25$ & $1 \mathrm{Ap} /$ & 80 & 4 & 2 & 17 & 170 & 1 & 0 & 692 & \\
\hline & $0-25$ & $2 \mathrm{Cg} /$ & 20 & 0.1 & 30 & 0 & 0 & 1 & 5 & 321 & 12 \\
\hline & $25-60$ & $2 \mathrm{Cgc1}$ & 0 & 0.1 & 1 & 15 & 160 & 1 & 0 & 411 & \\
\hline & $60-90$ & $2 \mathrm{Cg} 1$ & 0 & 0.1 & 1 & 12 & 170 & 1 & 0 & 411 & \\
\hline & $90-150$ & $2 \mathrm{Cgc} 2$ & 0 & 0.1 & 1 & 12 & 170 & 1 & 0 & 411 & 13 \\
\hline & $150-190$ & $2 \mathrm{Cg} 2$ & 0 & 0.1 & 1 & 12 & 160 & 1 & 0 & 411 & \\
\hline & $190-200$ & $3 \mathrm{Cg}$ & 0 & 0.1 & 1 & 26 & 140 & 1 & 0 & 412 & \\
\hline \multirow[t]{6}{*}{ Zand + $10 \mathrm{lk}$} & $0-25$ & $1 \mathrm{Ap} /$ & 60 & 4 & 2 & 17 & 170 & 1 & 0 & 692 & \\
\hline & $0-25$ & $2 \mathrm{Cg} /$ & 40 & 0.1 & 20 & 0 & 0 & 3 & 5 & 321 & \\
\hline & $25-50$ & $3 \mathrm{Cg} 1$ & 0 & 0.5 & 1 & 17 & 160 & 1 & 0 & 411 & 10 \\
\hline & $50-100$ & $3 \mathrm{Cu}$ & 0 & 0.2 & 1 & 12 & 160 & 1 & 0 & 413 & 11 \\
\hline & $100-180$ & $3 \mathrm{Cg} 2$ & 0 & 0.1 & 1 & 12 & 170 & 1 & 0 & 413 & \\
\hline & $180-190$ & $4 \mathrm{Cg}$ & 0 & 0.1 & 3 & 25 & 140 & 1 & 0 & 412 & \\
\hline \multirow[t]{6}{*}{ Zand + $10 \mathrm{zk}$} & $0-25$ & $1 \mathrm{Ap}$ & 0 & 4 & 2 & 20 & 180 & 1 & 0 & 692 & 16 \\
\hline & $25-40$ & $1 \mathrm{Bs}$ & 0 & 1 & 1 & 16 & 160 & 1 & 0 & 411 & 17 \\
\hline & $40-90$ & $1 \mathrm{Cu}$ & 0 & 0.1 & 1 & 14 & 180 & 1 & 0 & 413 & 18 \\
\hline & $90-150$ & $1 \mathrm{Cgc}$ & 0 & 0.1 & 1 & 14 & 160 & 1 & 0 & 413 & 19 \\
\hline & $150-180$ & $1 \mathrm{Cgr} 1$ & 0 & 0.1 & 1 & 16 & 150 & 1 & 0 & 412 & 20 \\
\hline & $180-190$ & 1Cgr2 & 0 & 0.1 & 2 & 24 & 140 & 1 & 0 & 412 & \\
\hline
\end{tabular}



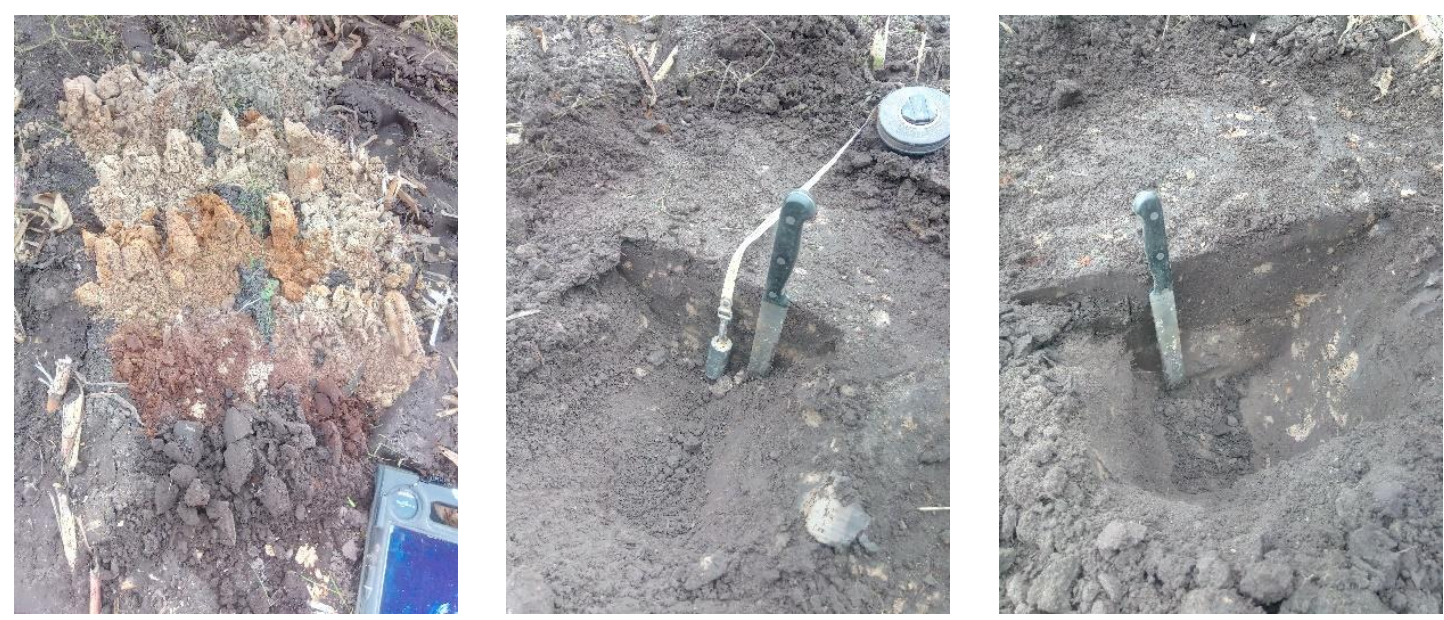

Zand met $5 \mathrm{~cm}$ zware klei

\section{Zand met $10 \mathrm{~cm}$ zware klei}
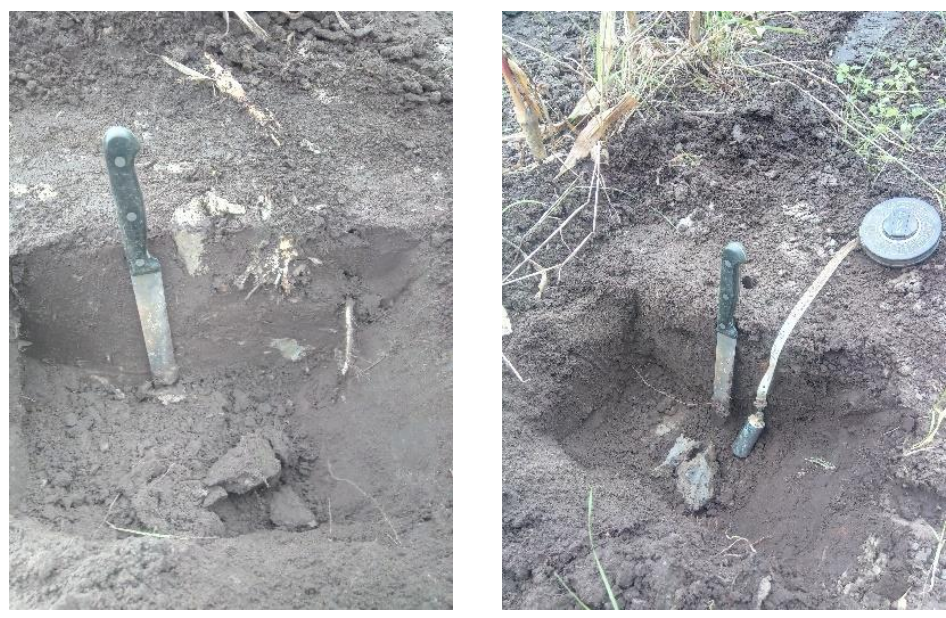

Figuur 2.3 Foto's (Willy de Groot, WENR) van bestaande zandprofiel en impressies van plots met menging van 5 en $10 \mathrm{~cm}$ lichte en zware klei in de bovenlaag.

Tabel 2.2 Enkele algemene kenmerken behorende bij de profielbeschrijvingen van de vijf klei-in-zandplots en de twee locaties waar de lichte en zware klei vandaan kwamen: veldschattingen van gemiddeld hoogste (GHG) en gemiddeld laagste (GLG) grondwaterstand (beide in cm -mv), grondwatertrapklasse (Gt) en bewortelingsdiepte $(\mathrm{cm}-\mathrm{mv})$ en hoogteligging $(m+N A P)$ en Rijksdriehoekstelselcoördinaten $(X, Y)$ van de locatie.

\begin{tabular}{llllllll}
\hline Plot & GHG & GLG & Gt & Beworteling & Hoogte & X & Y \\
\hline Zand & 160 & 220 & VIIId & 40 & 15.63 & 221190.741 & 450721.041 \\
\hline Zand + $10 \mathrm{lk}$ & 160 & 220 & VIIId & 35 & 15.69 & 221196.137 & 450725.514 \\
\hline Zand + $5 \mathrm{zk}$ & 160 & 220 & VIIId & 40 & 15.59 & 221190.737 & 450715.369 \\
\hline Zand + $5 \mathrm{lk}$ & 160 & 220 & VIIId & 35 & 15.50 & 221188.224 & 450708.615 \\
\hline Zand + 10 zk & 160 & 220 & VIIId & 35 & 15.51 & 221192.435 & 450701.479 \\
\hline Zware klei (zk), Tricht & 45 & 170 & (VI/Vio) & 40 & 1.78 & 145447.787 & 436513.749 \\
\hline Lichte klei (lk), Aerdt & 20 & 160 & (V/Vao) & 30 & 11.06 & 203984.187 & 433928.012 \\
\hline
\end{tabular}




\subsection{Grondmonsters}

In elke plot van perceel $\mathrm{K} 1$ alsook op de twee percelen van de kleilocaties zijn in de bovengrond duplo ongestoorde ringmonsters genomen voor de bepaling van de doorlatendheid bij verzadiging, en duplo ongestoorde ringmonsters voor de verdampingsmethode (laboratoriummethode ter bepaling van de waterretentie- en doorlatendheidskarakteristiek, zie paragraaf 2.4). Tevens zijn in de onbehandelde plot duplo ringmonsters voor beide type bepalingen genomen op dieptes 30-40 en 75-85 cm -mv. Dat is niet gedaan onder de behandelde plots, omdat de kleimenging geen invloed heeft op de fysische eigenschappen van de ondergrond. In de onbehandelde plots zijn ook in duplo ongestoorde kleine ringmonsters $\left(100 \mathrm{~cm}^{3}\right)$ genomen waarop aanvullende waterretentiemetingen zijn uitgevoerd. De kleine ringmonsters zijn niet genomen in de met klei behandelde plots. De reden hiervoor is dat de klei niet goed met het zand vermengd was, waardoor het niet goed mogelijk was om de juiste mengverhouding klei-zand in de kleine ringen te verkrijgen. In alle plots zijn gestoorde monsters genomen ter bepaling van het organischestofgehalte, de textuurverdeling en watergehalten in de drukpanmethode en luchtdroog. De gestoorde klei-in-zandmonsters moesten in het laboratorium handmatig in de gewenste klei-zandverhouding gemengd worden. Dat betekent dat de verkregen textuurverdeling als indicatief beschouwd moet worden. De gebruikte analysemethoden zijn te vinden in Bakker et al. (2020) en zijn hieronder kort omschreven. In Tabel 2.3 is een overzicht gegeven van type monsters en grootte van de monsters voor de verschillende bepalingsmethoden; het betreft hier BRO-conforme analyses.

Tabel 2.3 Informatie over type monsters dat per bepalingssoort is gebruikt. De bepalingen zijn voor alle behandelingen toegepast, tenzij anders aangegeven in de kolom Opmerking.

\begin{tabular}{|c|c|c|c|c|c|}
\hline Bepaling & (On)gestoord & $\begin{array}{l}\text { Diameter } \\
(\mathrm{cm})\end{array}$ & $\begin{array}{l}\text { Hoogte } \\
(\mathrm{cm})\end{array}$ & $\begin{array}{l}\text { Volume } \\
\left(\mathrm{cm}^{3}\right)\end{array}$ & Opmerking \\
\hline Doorlatendheid bij verzadiging & ongestoord, ring & 10.2 & 10.0 & 817.13 & \\
\hline Verdampingsmethode & ongestoord, ring & 20.0 & 10.0 & 3141.6 & \\
\hline Zandbak & ongestoord, ring & 5.05 & 5.0 & 100.15 & Niet voor de klei-in-zandbehandelingen \\
\hline Drukpan, luchtdroog & gestoord, zak"\# & n.v.t. & n.v.t. & n.v.t. & $\begin{array}{l}\text { Handmatig gemengd tot gewenste zand- } \\
\text { kleiverhouding, waarna gebruikt voor de } \\
\text { bepaling }\end{array}$ \\
\hline Textuur, OS & gestoord, zak $\#$ & n.v.t. & n.v.t. & n.v.t. & idem \\
\hline
\end{tabular}

\section{Doorlatendheid bij verzadiging}

De doorlatendheid bij verzadiging wordt gemeten aan een ongestoord monster. Deze wordt in een meetopstelling geplaatst en langzaam van onderaf verzadigd. Daarna wordt een constant waterlaagje boven op het monster gehandhaafd, waardoor water door het monster gaat stromen. Na verloop van tijd ontstaat een constant debiet dat gedeeld door het doorstroomde oppervlak gelijk is aan de doorlatendheid bij verzadiging.

Simultaan meten van waterretentie- en doorlatendheidskarakteristieken met de verdampingsmethode De ringmonsters worden eerst langzaam van onderaf verzadigd waarna ze weer uitlekken, totdat de onderkant net niet meer verzadigd is. De monsters worden op een meetopstelling geplaatst op een weegschaal en voorzien van vier tensiometers, verdeeld over de monsterhoogte. De monsters zullen water gaan verdampen aan de bovenzijde en de gewichtsafname (= verdamping) en de drukhoogtes gemeten met de tensiometers worden geregistreerd. De meting wordt beëindigd op het moment dat de tensiometers doorslaan. Na afloop worden de metingen analytisch verwerkt waarbij $\theta(h)$ - en $K(h)$-data worden verkregen welke vervolgens worden gefit aan de Mualem-Van Genuchten-vergelijkingen (zie paragraaf 2.4). Na afloop wordt de droge bulkdichtheid van het monster gemeten.

\section{Zandbak}

Voor het drukhoogtetraject $h=0 \mathrm{~cm}$ tot $h=-100 \mathrm{~cm}$ kunnen (kleine) ongestoorde ringmonsters op een zandbak geplaatst worden. In de zandbak kunnen dan stapsgewijs verschillende drukhoogtes worden opgelegd aan de ringmonsters, waarin dan het volumetrisch watergehalte kan worden gemeten. Deze metingen worden toegevoegd aan de data verkregen met de verdampingsmethode om de karakteristieken te fitten. $\mathrm{Na}$ afloop wordt de droge bulkdichtheid van het monster gemeten. 


\section{Drukpan}

Aanvullende $\theta(h)$-data voor zeer negatieve drukhoogte worden verkregen door gestoorde grondmonsters in een drukpan (overdruk = - drukhoogte) te plaatsen en nadat evenwicht is verkregen, wordt het bijbehorende watergehalte gemeten. Meestal worden hiertoe drukhoogtes van circa -1000 à $-3000 \mathrm{~cm}$ en circa -14000 à $-16000 \mathrm{~cm}$ aangehouden. Deze metingen worden toegevoegd aan de data verkregen met de verdampingsmethode om de karakteristieken te fitten.

\section{Luchtdroog}

Een gestoord monster wordt in het laboratorium gedroogd. Luchtdroge grond heeft onder die omstandigheden een drukhoogte van circa $-10^{6} \mathrm{~cm}$. Deze metingen worden toegevoegd aan de data verkregen met de verdampingsmethode om de karakteristieken te fitten.

\section{Organischestofgehalte}

Het organischestofgehalte wordt bepaald volgens de gloeiverliesmethode. Hiertoe wordt een gestoord monster sterk verhit $\left(550^{\circ} \mathrm{C}\right)$, waardoor de aanwezige organische stof verbrandt, wat leidt tot een gewichtsverlies. Na afloop kan een correctie toegepast worden voor aanwezigheid van lutum en vrij ijzer. De gegevens worden uitgedrukt als een gewichtsfractie.

\section{Textuurverdeling}

De textuurverdeling geeft de gewichtsfracties weer van de aanwezige bodemdeeltjes. Hierbij worden de volgende klassen onderscheiden (eenheid: $\mu \mathrm{m}$ ): $<2,2-16,16-50,50-63,63-105,105-150,150-210$, 210-420, en 420-2000. De eerste drie klassen worden gemeten met de pipetmethode, de klasse 50-63 wordt gemeten met de natte zeefmethode en de overige vijf klassen met de droge zeefmethode. De gegevens worden uitgedrukt als een gewichtsfractie.

Zoals hierboven vermeld, zijn voor de klei-in-zandplots geen kleine ringmonsters $\left(100 \mathrm{~cm}^{3}\right)$ genomen. In dit soort type monsters worden enkele datapunten voor $\theta(h)$ verkregen die bij de dataverwerking van de verdampingsmethode meegenomen (kunnen) worden bij het vaststellen van de waterretentiekarakteristiek. Deze meetpunten worden vooral gebruikt om vast te stellen of de verkregen data van de verdampingsmethode van de juiste ordegrootte zijn. Het ontbreken van deze aanvullende meetpunten heeft geen grote invloed op de parameterschattingen van de Mualem-Van Genuchten-parameters (zie paragraaf 2.4). Dat betekent dat ook voor de klei-in-zandbehandelingen nog steeds een goede schatting van de waterretentie- en doorlatendheidskarakteristiek verkregen kan worden.

\subsection{Waterretentie- en doorlatendheidskarakteristieken}

Met de verdampingsmethode wordt gelijktijdig de waterretentie- en de doorlatendheidskarakteristiek bepaald welke beschreven zijn volgens de functionele beschrijvingen van Van Genuchten (1980) en Mualem (1976). De waterretentiekarakteristiek is gegeven als

$$
\theta(h)=\theta_{r}+\frac{\left(\theta_{s}-\theta_{r}\right)}{\left(1+|\alpha h|^{n}\right)^{m}}
$$

en de doorlatendheidskarakteristiek is gegeven als (onder de voorwaarde dat $m=1-1 / n$ )

$$
K(h)=K_{\mathrm{s}} \frac{\left(\left(1+|\alpha h|^{\mathrm{n}}\right)^{\mathrm{m}}-|\alpha h|^{\mathrm{n}-1}\right)^{2}}{\left(1+|\alpha h|^{\mathrm{n}}\right)^{\mathrm{m}(\lambda+2)}}
$$

Hierin is $\theta$ het volumetrisch watergehalte $\left(\mathrm{cm}^{3} \mathrm{~cm}^{-3}\right), h$ is de drukhoogte $(\mathrm{cm}), K$ is de hydraulische doorlatendheid $\left(\mathrm{cm} \mathrm{d}^{-1}\right)$; de parameters zijn: $\theta_{\mathrm{r}}$ is een (asymptotisch) residueel watergehalte $\left(\mathrm{cm}^{3} \mathrm{~cm}^{-3}\right), \theta_{\mathrm{s}}$ is $\theta$ bij verzadiging $\left(\mathrm{cm}^{3} \mathrm{~cm}^{-3}\right), K_{\mathrm{s}}$ is $K$ bij verzadiging $\left(\mathrm{cm} \mathrm{d}^{-1}\right)$, en $\alpha\left(\mathrm{cm}^{-1}\right), n, m$, en $\lambda$ (alle dimensieloos) zijn vormparameters. De curves en bijbehorende parameters worden gerapporteerd. 


\subsection{Waterbeschikbaarheid en kritieke flux}

Eén manier om bodems te beoordelen, is op basis van de waterbeschikbaarheid voor het gewas. Dit gebeurt door het verschil in watergehalte bij veldcapaciteit $(h=-100 \mathrm{~cm})$ en bij verwelkingspunt $(h=-16000 \mathrm{~cm})$ te bepalen uit de waterretentiekarakteristiek. Dit verschil wordt dan vermenigvuldigd met de dikte van de wortelzone, hiervoor wordt in de praktijk meestal de laag $\Delta z_{r}(30 \mathrm{~cm}$ of $300 \mathrm{~mm}$ ) beschouwd. In formulevorm:

$$
W_{\mathrm{av}}=\Delta Z_{\mathrm{r}}\left(\theta_{-100}-\theta_{-16000}\right)
$$

Soms wordt hierbij onderscheid gemaakt tussen gemakkelijk beschikbaar water en moeilijk beschikbaar water met als tussenwaarde het watergehalte bij $h=-400 \mathrm{~cm}$ :

$$
\begin{gathered}
W_{\mathrm{av}, 1}=\Delta Z_{\mathrm{r}}\left(\theta_{-100}-\theta_{-400}\right) \\
W_{\mathrm{av}, 2}=\Delta Z_{\mathrm{r}}\left(\theta_{-400}-\theta_{-16000}\right)
\end{gathered}
$$

waarbij geldt dat $W_{\mathrm{av}}=W_{\mathrm{av}, 1}+W_{\mathrm{av}, 2}(\mathrm{~cm}$ of $\mathrm{mm})$.

Naast de statische waterbeschikbaarheid kan ook gekeken worden naar de mogelijkheid dat water vanuit het grondwater via capillaire opstijging in de bovengrond beschikbaar wordt gesteld. In het verleden werd hiervoor vaak de kritieke stijghoogte van bodemprofielen bepaald. Dat is de afstand tussen de grondwaterstand en de onderkant van de wortelzone waarbij het tussenliggende bodemprofiel nog een stationaire flux van $2 \mathrm{~mm} \mathrm{~d}^{-1}$ de wortelzone in kan leveren. Deze maat is voor deze proef niet interessant, omdat de kleitoevoeging heeft plaatsgevonden in de bovenste $30 \mathrm{~cm}$ (= wortelzone). De (veranderde) eigenschappen van deze bovenlaag worden dus niet meegenomen in de berekening van de kritieke stijghoogte, en de kritieke stijghoogte zal voor alle behandelingen hetzelfde zijn.

In dit onderzoek wordt daarom gebruikgemaakt van de kritieke flux (Heinen et al., 2021). De kritieke flux $\left(q_{\text {crit }}, \mathrm{cm} \mathrm{d}^{-1}\right)$ is de opwaartse flux die nog door het hele profiel geleverd kan worden aan maaiveld indien de grondwaterspiegel aan de onderzijde van het bodemprofiel ligt $(120 \mathrm{~cm})$. Deze kan worden berekend via de oplossing van de volgende vergelijking:

$$
\int_{-160000}^{0} \frac{K(h)}{K(h)+q_{\text {crit }}} \mathrm{d} h=120
$$

De kritieke flux kan iteratief berekend worden; details zijn te vinden in Heinen et al. (2021).

\subsection{Simulatie}

Om na te gaan in hoeverre de veranderingen in waterretentie- en doorlatendheidskarakteristieken als gevolg van de kleibijmenging leiden tot veranderingen in droogte- en zuurstofstress en daarmee drogestofproductie voor mais, zijn met SWAP-WOFOST (Kroes et al., 2017) simulaties uitgevoerd voor de uitgangssituatie (zand zonder klei toegevoegd) en voor de vier situaties met 5 en $10 \mathrm{~cm}$ lichte en zware kleitoevoegingen. Als basis wordt gebruikt een set invoerbestanden uit de Waterwijzer Landbouw maatwerkoptie (www.waterwijzerlandbouw.wur.nl) voor BOFEK2020 cluster 3015 (Heinen et al., 2021) met gewas mais (inclusief winter vanggewas), meteostation De Bilt en met GHG $=160 \mathrm{~cm}-\mathrm{mv}$ en GLG $=220 \mathrm{~cm}-\mathrm{mv}$ (Tabel 2.2): hiervoor is run 132155 geselecteerd (WWL maatwerktool versie 2.0.4; database versie 3.0.0). De waterretentie- en doorlatendheidskarakteristieken worden aangepast aan de gemeten situatie. De simulatieperiode is $1975-2020$. 


\section{Resultaten en discussie}

\section{$3.1 \quad$ Textuur}

De textuurverdelingen en organischestofgehalten van de monsters (duplo) zijn gegeven in Tabel 3.1. Voor het oorspronkelijke zandprofiel geldt dat de drie bemonsterde bodemlagen op basis van het leemgehalte als leemarm, zeer fijn tot matig fijn zand aangeduid moeten worden, hetgeen overeenkomt met Staringreeks bouwsteen B1 en $\mathrm{O} 1$ (Heinen et al., 2020). Volgens de veldschattingen (Tabel 2.1) zouden de leemgehaltes iets hoger zijn, hetgeen past bij de BOFEK2020-kaart (Heinen et al., 2021), waaruit blijkt dat het perceel in cluster 3015 ligt: B2 op O2.

Volgens de gemeten lutumgehalten is het monster uit Aerdt (Ik) een matig lichte zavel (B8) en het monster uit Tricht (zk) een zeer zware klei (B12). Volgens de veldschatting van het lutumgehalte is het monster uit Tricht licht tot matig zware klei.

Het organischestofgehalte (OS) van de lichte klei was lager dan die in de referentiezandmonsters, en die voor de zware klei was hoger. Voor de klei-in-zandmonsters zien we dat voor de situatie met lichte klei het OS iets lager wordt en voor de situatie met zware klei juist wat hoger in vergelijking met de referentiezandmonsters. Het betreft dan een verandering van een paar tienden procentpunten $(<0,5 \%)$.

Het lutumgehalte voor lichte en zware klei was hoger dan die in het zand en in de klei-in-zandmonsters neemt dan ook het lutumgehalte toe met het aandeel lichte en zware klei. We hebben niet nagerekend of de verkregen OS- en lutumgehalten in de mengmonsters overeenkomen met de veronderstelde mengverhouding van klei en zand. Dit omdat niet met zekerheid bekend is i) of de toevoeging exact 5 en $10 \mathrm{~cm}$ is geweest, ii) tot welke diepte de klei exact is gemengd met het zand, en iii) of de monsters die in het laboratorium op het oog gemengd zijn dezelfde klei-in-zandverhouding hadden als die in het veld. Omdat de klei niet uniform verdeeld was in de grondmonsters, moest handmatig en op het oog de kleibrokken en het zand in een gewenste verhouding vermalen worden. Hier moeten we dus volstaan met de waarneming dat inderdaad door de menging van klei in zand het gehalte oS en de textuurverdeling beïnvloed wordt.

De lutumgehalten van de klei-in-zandmonsters waarbij $10 \mathrm{~cm}$ klei is toegevoegd, zijn gemiddeld hoger dan $8 \%$. Dat betekent dat deze bovengronden volgens de textuurindeling van de Nederlandse bodemkaart en de Staringreeks gerekend moeten gaan worden tot de zeer lichte zavelbovengronden (B9). Bij grootschalige toepassingen van klei-in-zand kan dat mogelijk in de toekomst consequenties hebben voor de Nederlandse bodemkaart (1:50.000) en de bodemfysische eenhedenkaart (BOFEK2020). Omdat de lichte klei een lager lutumgehalte heeft dan de zware klei, zijn de toenames in lutumgehalten bij bijmenging van lichte klei geringer dan bij bijmenging van zware klei. 
Tabel 3.1 Organischestofgehalten (OS) en textuurverdeling (allen in gewichtspercentages) van de duplomonsters.

\begin{tabular}{|c|c|c|c|c|c|c|c|c|c|c|c|}
\hline Monster & $\begin{array}{l}\text { Diepte } \\
\text { (cm-mv) }\end{array}$ & $\begin{array}{r}\text { OS } \\
(\%)\end{array}$ & $\begin{array}{l}0-2 \\
(\%)\end{array}$ & $\begin{array}{l}2-16 \\
(\%)\end{array}$ & $\begin{array}{r}16-50 \\
(\%)\end{array}$ & $\begin{array}{r}50-63 \\
(\%)\end{array}$ & $\begin{array}{r}\text { 63-105 } \\
(\%)\end{array}$ & $\begin{array}{r}105-150 \\
(\%)\end{array}$ & $\begin{array}{r}150-210 \\
(\%)\end{array}$ & $\begin{array}{r}210-420 \\
(\%)\end{array}$ & $\begin{array}{r}420-2000 \\
(\%)\end{array}$ \\
\hline \multirow[t]{6}{*}{ Zand (Z) } & $3-13$ & 5.42 & 3.5 & 3.1 & 4.3 & 2.3 & 17.8 & 24.4 & 23.9 & 13.1 & 5.3 \\
\hline & & 5.31 & 3.3 & 1.5 & 4.0 & 1.3 & 16.8 & 25.2 & 24.8 & 14.1 & 5.6 \\
\hline & $30-40$ & 6.74 & 2.5 & 2.7 & 2.9 & 1.5 & 15.1 & 25.3 & 25.8 & 15.7 & 6.5 \\
\hline & & 5.87 & 2.5 & 1.4 & 2.9 & 1.2 & 13.0 & 27.5 & 28.2 & 15.4 & 6.4 \\
\hline & $75-85$ & 0.50 & 1.0 & 0.8 & 0.9 & 0.9 & 16.9 & 28.9 & 27.8 & 15.2 & 4.8 \\
\hline & & 0.45 & 1.2 & 0.5 & 0.7 & 0.6 & 14.5 & 28.5 & 29.4 & 16.3 & 5.2 \\
\hline \multirow[t]{2}{*}{ Lichte klei Ik } & $2-12$ & 3.12 & 17.3 & 13.7 & 10.5 & 1.1 & 5.7 & 8.1 & 15.2 & 22.9 & 3.8 \\
\hline & & 3.05 & 18.8 & 14.3 & 10.8 & 1.7 & 5.9 & 7.5 & 14.8 & 21.0 & 3.4 \\
\hline \multirow[t]{2}{*}{ Zware klei zk } & $13-23$ & 8.80 & 51.9 & 22.6 & 10.8 & 1.2 & 4.5 & 2.6 & 1.7 & 2.0 & 2.0 \\
\hline & & 9.82 & 53.4 & 24.5 & 10.0 & 1.7 & 3.1 & 2.6 & 1.5 & 1.8 & 1.2 \\
\hline \multirow[t]{2}{*}{$\mathrm{Z}+5 \mathrm{lk}$} & $3-13$ & 4.89 & 6.5 & 4.0 & 5.3 & 2.1 & 13.2 & 23.0 & 22.5 & 14.6 & 6.9 \\
\hline & & 4.68 & 5.5 & 5.4 & 5.4 & 2.2 & 12.0 & 21.9 & 23.6 & 15.7 & 7.3 \\
\hline \multirow[t]{2}{*}{$\mathrm{Z}+10 \mathrm{lk}$} & $3-13$ & 5.16 & 8.4 & 6.4 & 6.8 & 1.7 & 11.6 & 19.3 & 21.3 & 16.1 & 6.8 \\
\hline & & 4.33 & 12.2 & 9.3 & 6.5 & 2.1 & 10.6 & 17.6 & 19.2 & 15.8 & 6.0 \\
\hline \multirow[t]{2}{*}{$\mathrm{z}+5 \mathrm{zk}$} & $3-13$ & 5.69 & 5.3 & 2.8 & 4.0 & 1.7 & 12.8 & 25.5 & 25.1 & 14.1 & 7.1 \\
\hline & & 5.94 & 3.8 & 3.1 & 3.9 & 2.3 & 15.0 & 27.4 & 24.3 & 12.8 & 5.5 \\
\hline \multirow[t]{2}{*}{$\mathrm{Z}+10 \mathrm{zk}$} & $3-13$ & 5.65 & 11.1 & 5.6 & 4.3 & 1.8 & 12.3 & 24.4 & 21.4 & 12.1 & 5.1 \\
\hline & & 5.64 & 7.1 & 5.4 & 4.5 & 2.0 & 16.3 & 21.2 & 23.1 & 13.3 & 5.0 \\
\hline
\end{tabular}

\subsection{Verdampingsmethode: Mualem-Van Genuchten- parameters}

In Tabel 3.2 zijn de verkregen Mualem-Van Genuchten-parameters gegeven voor alle afzonderlijke (duplo)bodemmonsters. De grafische weergave van de curves is gegeven in Figuur 3.1 en 3.2. Behalve bij de $10 \mathrm{~cm}$ zware klei in zandmonsters geldt dat de curves van de duplomonsters vrij dicht bij elkaar liggen. De curves zijn gegeven voor i) ongemengde zand, lichte en zware klei monsters, ii) voor de $5 \mathrm{~cm}$ klei-inzandmonsters in vergelijking met de zandmonsters, en iii) voor de $5 \mathrm{~cm}$ klei-in-zandmonsters in vergelijking met de zandmonsters. Hieruit wordt duidelijk dat de toevoeging van klei leidt tot aanpassing van de hydraulische eigenschappen. De curves voor zand worden daarbij aangepast richting de curves van de pure klei; dat geldt niet voor de $10 \mathrm{~cm}$ lichte klei in zandmonsters nabij verzadiging. Mogelijk dat de monsters van dit specifieke plot niet de gewenste klei-zandverhouding hadden. De monsters zijn achteraf niet gecontroleerd op feitelijk mengverhouding klei-zand.

Bij extreem droge omstandigheden wordt iets meer water vastgehouden in de klei-in-zandmonsters dan in de zandmonsters. Dit is in overeenstemming met Betti et al. (2016), die concludeerden dat de toevoeging van klei resulteert in een verandering van de vorm van de waterretentiekarakteristiek.

De interpretatie van de doorlatendheidskarakteristieken is lastiger, hetgeen mede wordt veroorzaakt door de grote ranges in $h$ en $K$. De implicaties hiervan worden besproken in paragraaf 3.3 (Waterbeschikbaarheid en kritieke flux).

Bij de uitwerking van de meetgegevens voor de klei-in-zandmonsters bleek vaak dat de afgeleide doorlatendheden in het natte traject niet goed passen bij de vorm volgens de Mualem-curve (zie voorbeelden in Bijlage 2). Zeer waarschijnlijk is dit toe te schrijven aan de slechte menging van de klei in het zand. De klei was vaak aanwezig als grote aggregaten. Hierdoor is sprake van ruimtelijke variabiliteit in de poriëngrootteverdeling. Tijdens het bepalen van de Mualem-Van Genuchten-parameters wordt meer gewicht toegekend aan de waterretentiegegevens dan aan de doorlatendheidgegevens, zodat het genoemde afwijkende patroon waarschijnlijk geen aanleiding zal zijn voor niet-realistische parameterschattingen. 
Tabel 3.2 De Mualem-Van Genuchten-parameters voor de afzonderlijke monsters inclusief de droge bulkdichtheid van de monsters.

\begin{tabular}{|c|c|c|c|c|c|c|c|c|}
\hline Monster & $\begin{array}{l}\text { Diepte } \\
\text { (cm-mv) }\end{array}$ & $\begin{array}{r}\theta_{r} \\
\left(m^{3} m^{-3}\right)\end{array}$ & $\begin{array}{r}\theta_{s} \\
\left(m^{3} m^{-3}\right)\end{array}$ & $\begin{array}{r}\alpha \\
\left(\mathrm{cm}^{-1}\right)\end{array}$ & $\begin{array}{r}n \\
(-)\end{array}$ & $\begin{array}{r}\lambda \\
(-)\end{array}$ & $\begin{array}{r}K_{s} \\
\left(\mathrm{~cm} \mathrm{~d}^{-1}\right)\end{array}$ & $\begin{array}{r}\text { Dichtheid } \\
\left(\mathrm{kg} \mathrm{m}^{-3}\right)\end{array}$ \\
\hline \multirow[t]{6}{*}{ Zand } & $3-13$ & 0 & 0.3985 & 0.004594 & 1.4270 & 3.0000 & 2.034 & 1541 \\
\hline & $3-13$ & 0 & 0.4017 & 0.005877 & 1.3887 & 3.0323 & 3.179 & 1524 \\
\hline & $30-40$ & 0.0387 & 0.4488 & 0.020136 & 1.4067 & 0.5673 & 100.248 & 1352 \\
\hline & $30-40$ & 0.0532 & 0.4588 & 0.019216 & 1.4730 & 3.5598 & 314.913 & 1401 \\
\hline & $75-85$ & 0.0200 & 0.3158 & 0.014452 & 2.6103 & 0.7676 & 25.178 & 1688 \\
\hline & $75-85$ & 0.0150 & 0.3411 & 0.013033 & 2.6143 & 1.7829 & 51.708 & 1774 \\
\hline \multirow[t]{2}{*}{ Lichte klei (Ik) } & $2-12$ & 0 & 0.3719 & 0.011481 & 1.1790 & 4.7378 & 14.700 & 1694 \\
\hline & $2-12$ & 0 & 0.3851 & 0.016079 & 1.1650 & 0.0001 & 5.842 & 1714 \\
\hline \multirow[t]{2}{*}{ Zware klei (zk) } & $13-23$ & 0 & 0.5490 & 0.009253 & 1.1560 & 12.4084 & 5.199 & 1260 \\
\hline & $13-23$ & 0 & 0.5440 & 0.010104 & 1.1650 & 13.0168 & 3.933 & 1216 \\
\hline \multirow[t]{2}{*}{ Zand + $5 \mathrm{lk}$} & $3-13$ & 0.0263 & 0.3900 & 0.005311 & 1.5463 & 3.3693 & 7.003 & 1504 \\
\hline & $3-13$ & 0.0241 & 0.3900 & 0.005603 & 1.4978 & 2.7453 & 3.706 & 1514 \\
\hline \multirow[t]{2}{*}{ Zand + $10 \mathrm{lk}$} & $3-13$ & 0 & 0.4058 & 0.005591 & 1.3356 & 3.0000 & 5.640 & 1564 \\
\hline & $3-13$ & 0 & 0.3988 & 0.009663 & 1.2862 & 4.0000 & 34.790 & 1501 \\
\hline \multirow[t]{2}{*}{ Zand +5 zk } & $3-13$ & 0.0321 & 0.4300 & 0.006276 & 1.5116 & 6.6143 & 12.255 & 1413 \\
\hline & $3-13$ & 0.0302 & 0.4200 & 0.006570 & 1.4848 & 4.3262 & 7.380 & 1454 \\
\hline \multirow[t]{2}{*}{ Zand $+10 \mathrm{zk}$} & $3-13$ & 0 & 0.4382 & 0.006537 & 1.2952 & 2.5000 & 3.989 & 1473 \\
\hline & $3-13$ & 0 & 0.4724 & 0.006915 & 1.2982 & 3.8322 & 4.348 & 1320 \\
\hline
\end{tabular}




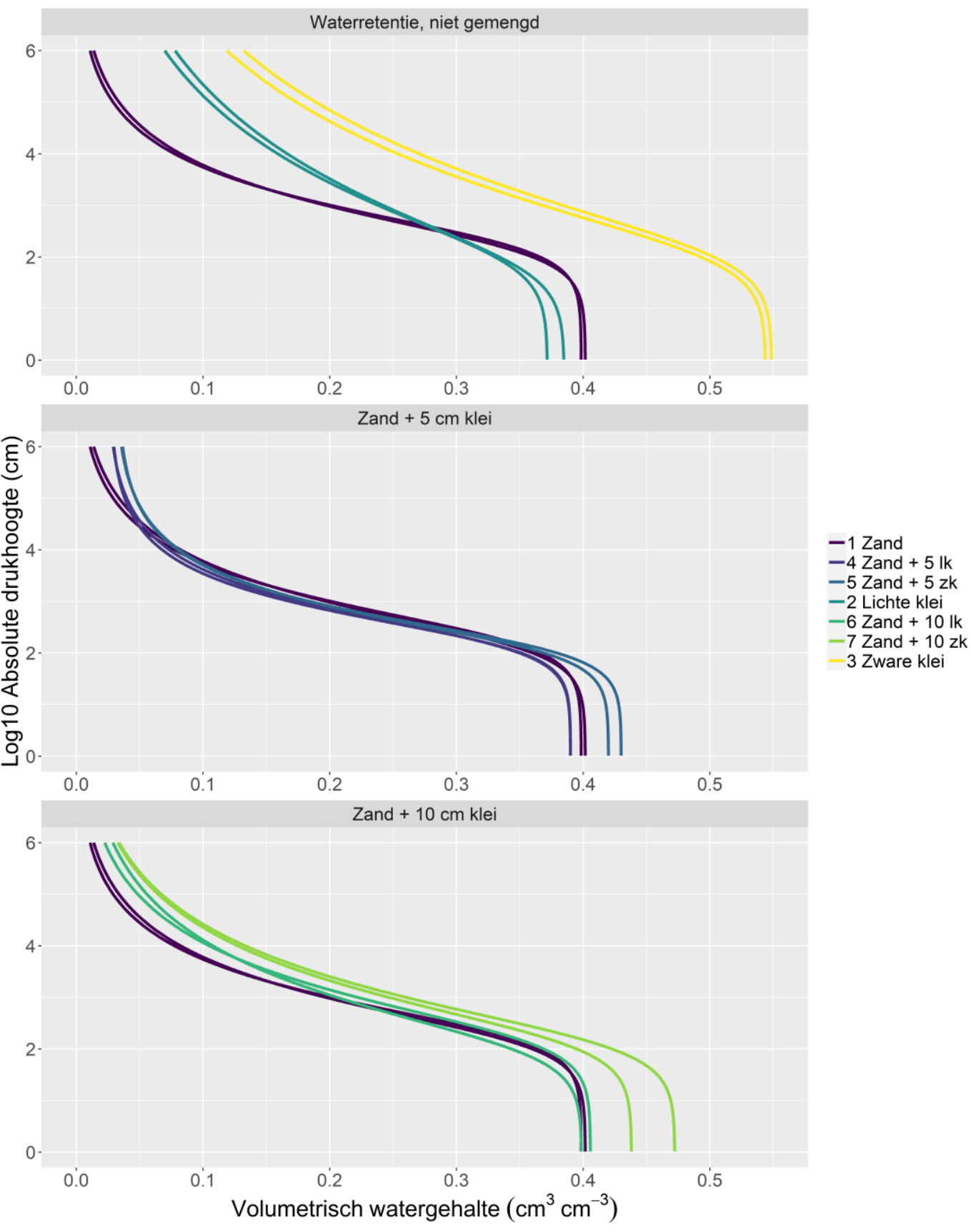

Figuur 3.1 De waterretentiekarakteristieken (duplo) voor (bovenste panel) de niet-gemengde zand-, lichte klei- en zware kleimonsters van de bovenlaag, (middelste panel) de $5 \mathrm{~cm}$ klei-in-zandmonsters in vergelijking met zand en (onderste panel) de $10 \mathrm{~cm}$ klei-in-zandmonsters in vergelijking met zand. 


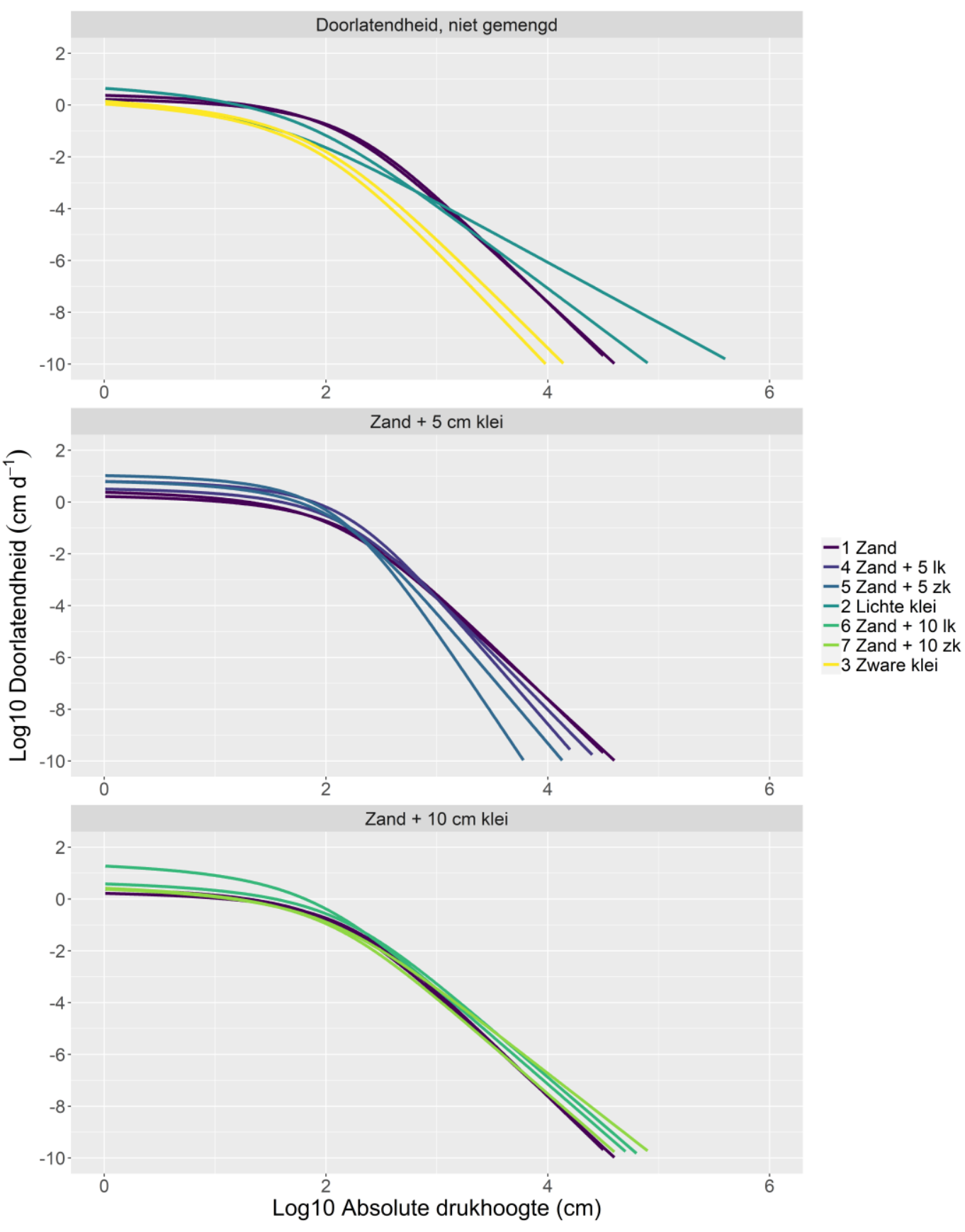

Figuur 3.2 De doorlatendheidskarakteristieken (duplo) voor (bovenste panel) de niet-gemengde zand-, lichte klei- en zware kleimonsters van de bovenlaag, (middelste panel) de $5 \mathrm{~cm}$ klei-in-zandmonsters in vergelijking met zand, en (onderste panel) de $10 \mathrm{~cm}$ klei-in-zandmonsters in vergelijking met zand.

\subsection{Waterbeschikbaarheid en kritieke flux}

Figuur 3.3 toont de waterbeschikbaarheid voor de zeven bovengronden (gemiddelden van twee monsters). De waterbeschikbaarheid voor de lichte klei is duidelijk geringer dan die voor zand. We zien dat ook terug in de verlaagde $W_{a v}$ voor de lichte klei-in-zandmonsters. Ook $W_{a v}$ voor de zware klei is iets lager dan voor zand. Maar deze is nauwelijks veranderd in de zware klei-in-zandmonsters. Voor de beide $5 \mathrm{~cm}$ klei-inzandsituaties is een lichte verschuiving zichtbaar in de verdeling van $W_{\text {av }}$ ten gunste van het makkelijk opneembaar water $\left(W_{\mathrm{av}, 1}\right)$. Dat is niet het geval voor de $10 \mathrm{~cm}$ klei-in-zandsituatie. 


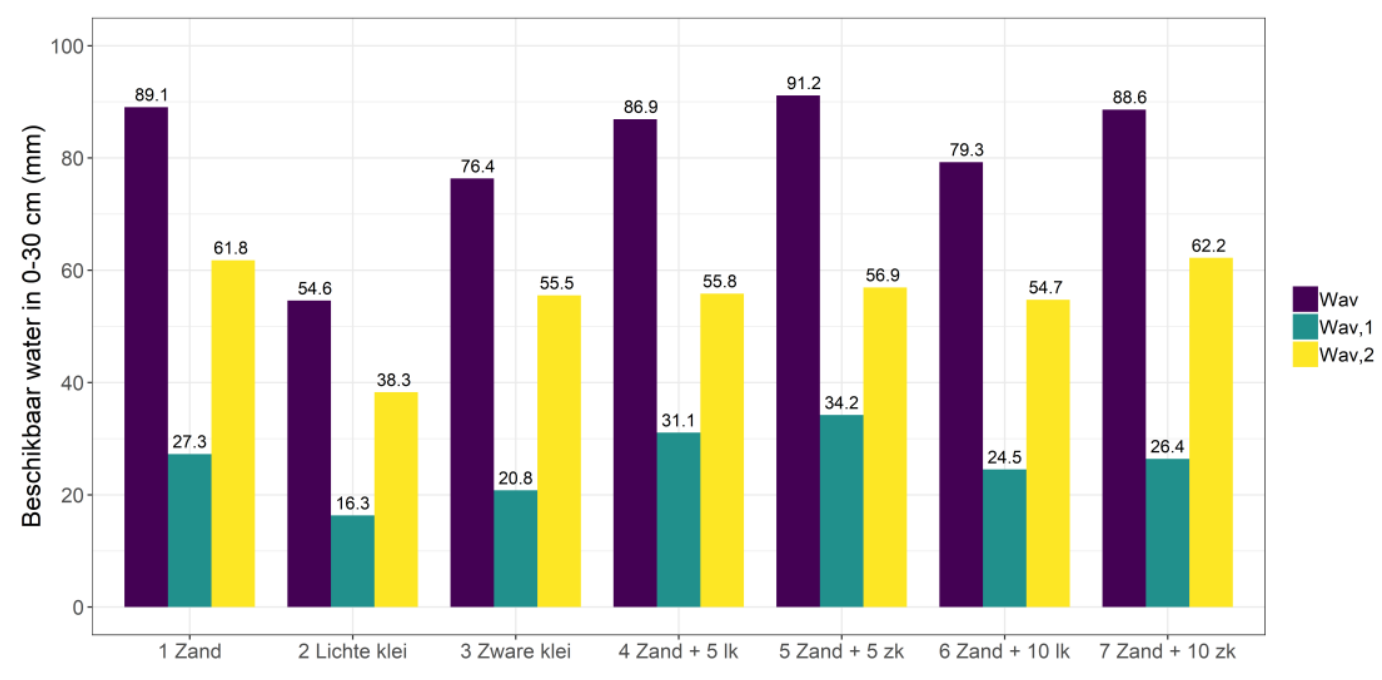

Figuur 3.3 Waterbeschikbaarheid in de laag 0-30 cm, berekend uit de waterretentiekarakteristieken voor de zeven bovengrondmonsters: $W_{a v}$ : totaal, $W_{a v, 1}$ : makkelijk, $W_{a v, 2}$ : moeilijk.

Betti et al. (2016) concludeerden dat de toevoeging van klei resulteert in een verandering van de vorm van de waterretentiekarakteristiek en dientengevolge in de waterbeschikbaarheid, welke toeneemt met toenemend kleigehalte en welke met name duidelijk was bij klei-zandverhoudingen van 10-20\%. Dit volgt niet uit de resultaten verkregen in deze studie. Deze auteurs gaven ook aan dat bij hogere kleizandmengverhoudingen (40-60\%) dit effect weer afneemt. Volgens de veldschattingen (Tabel 2.1) was de klei-zandverhouding in de plots $20-40 \%$. Omdat het soort zand en het type klei dat zij gebruikt hebben zeer waarschijnlijk anders is dan het zand en de klei in onze proef, kunnen we geen harde conclusie trekken.

Figuur 3.4 toont de kritieke flux voor de vijf profielen op De Marke. Behalve voor het profiel met $10 \mathrm{~cm}$ zware klei gemengd in de bovengrond, zijn de kritieke fluxen voor de profielen met kleitoevoegingen in de bovengrond groter dan die voor de referentiesituatie. De statische waterbeschikbaarheid (zie hiervoor) was weliswaar nauwelijks beïnvloed door de kleitoevoegingen, maar hier zien we dat de kleitoevoegingen er wel toe kunnen leiden dat er meer water via capillaire nalevering beschikbaar gesteld kan worden.

De berekeningen zijn uitgevoerd voor de afzonderlijke monsters van de bovenlagen; voor de midden- en onderlagen zijn gemiddelde eigenschappen gebruikt, waarbij de Mualem-Van Genuchten-parameters (zie Tabel 3.2) rekenkundig zijn gemiddeld.

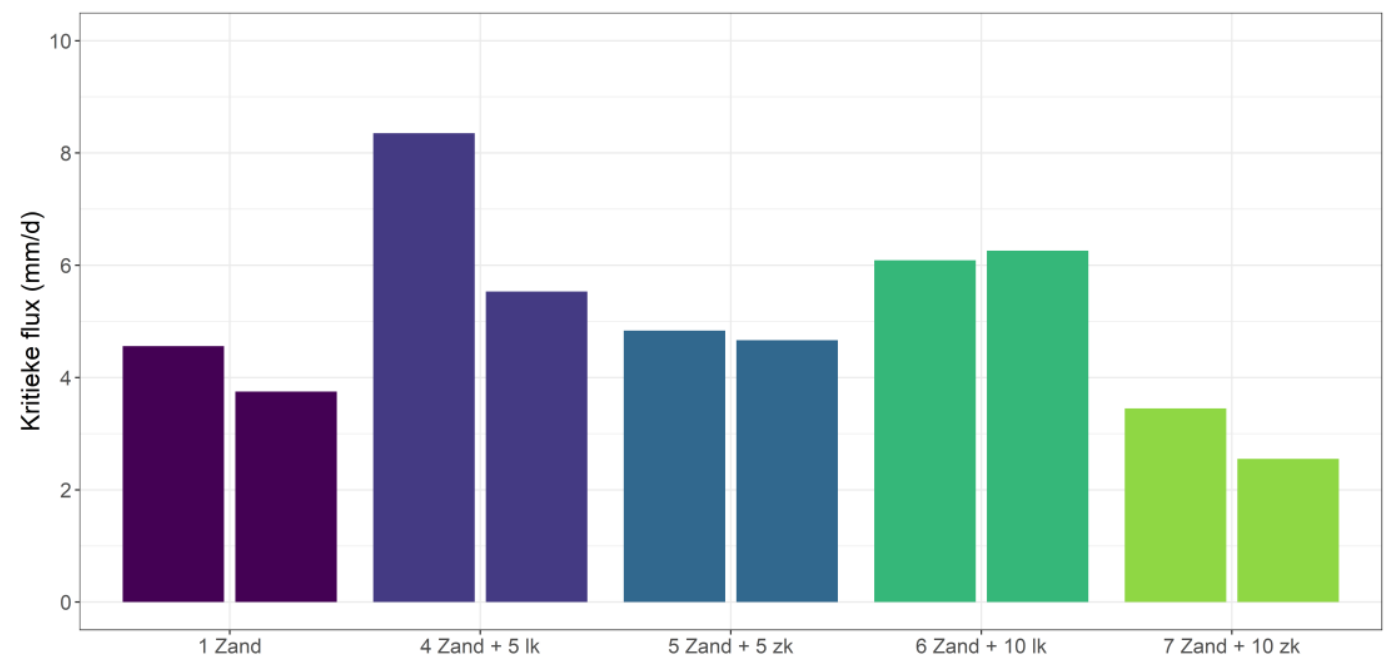

Figuur 3.4 Kritieke flux voor de vijf klei-in-zandbehandelingen op proefbedrijf De Marke. 


\subsection{Aanvullende metingen}

De gemeten $K_{\text {sat }}$ in de klei-in-zandmonsters zijn voor de behandelingen waarin $5 \mathrm{~cm}$ klei is toegediend iets lager dan die gemeten in de onbehandelde zandplot (Tabel 3.3). Echter, wanneer $10 \mathrm{~cm}$ klei is gemengd met het zand, dan is $K_{\text {sat }}$ daarin vergelijkbaar met die van zand (Tabel 3.3). Lichte klei heeft een iets lagere waarde voor $K_{\text {sat, }}$ maar die voor de zware klei is veel hoger. Er lijkt, op basis van deze beperkte set waarnemingen, geen duidelijk effect te zijn van de toegediende klei op $K_{\text {sat. }}$ In andere studies (zie Bijlage 1 ) zijn wel duidelijke effecten gerapporteerd. Soms betreft dat de invloed van het sterk zwellende kleimineraal bentoniet met een zeer lage waarde voor $K_{\text {sat }}$ of voor klei-zandmengsels die onder laboratoriumomstandigheden uniform gemengd zijn. Betti et al. (2016) gaven aan dat de grootte van de kleiaggregaten niet van grote invloed was op de effecten. Hun grootste aggregaten waren 4,5 cm in diameter. In onze klei-in-zandmonsters kwamen kleiklonten voor in allerlei maten en vormen, waarbij sommige klonten mogelijk groter waren dan 4,5 cm in diameter (zie Figuur 2.3 en 3.5). De toediening van de klei op proefboerderij De Marke vond plaats toen de klei relatief nat was, waardoor het niet goed vermalen werd door de verspreider. Wanneer in de toekomst de klei in wat meer uniforme en kleinere aggregaten wordt toegediend aan zand, dan verdient het aanbeveling om de invloed van de hoeveelheid klei op $K_{\text {sat }}$ opnieuw te meten (in meerdere herhalingen).

De aanvullende waterretentiemetingen uit Tabel 3.3 zijn meegenomen in de analyse van de verdampingsmetingen zoals hiervoor beschreven.

Tabel 3.3 Gemeten doorlatendheid bij verzadiging ( $\left.\mathrm{cm} \mathrm{d}^{-1}\right)$ en volumetrische watergehalten $\left(\mathrm{cm}^{3} \mathrm{~cm}^{-3}\right)$ bij verschillende ingestelde drukhoogtes ( $h$; -3 tot en met $-100 \mathrm{~cm}$ : zandbakmethode; -2620 en $-14000 \mathrm{~cm}$ : drukpanmethode; $-10^{6} \mathrm{~cm}$ : luchtdroog-methode) en de droge bulkdichtheid in $100 \mathrm{~cm}^{3}$ ringmonsters (zoals gebruikt bij de zandbakmethode).

\begin{tabular}{|c|c|c|c|c|c|c|c|c|c|c|c|}
\hline Monster & $\begin{array}{l}\text { Laag } \\
(\mathrm{cm}-\mathrm{mv})\end{array}$ & $\begin{array}{r}K_{\text {sat }} \\
\left(\mathrm{cm} \mathrm{d}^{-1}\right)\end{array}$ & $\begin{array}{r}h(\mathrm{~cm}) \\
-3\end{array}$ & -10 & -30 & $-60 /-70^{\$}$ & -100 & -2620 & -14000 & $-10^{6}$ & $\begin{array}{r}\text { Dichtheid } \\
\left(\mathrm{kg} \mathrm{m}^{-3}\right)\end{array}$ \\
\hline \multirow[t]{6}{*}{ Zand } & 3-13 & 9.7 & 0.389 & 0.381 & 0.375 & 0.366 & 0.354 & 0.103 & 0.101 & 0.026 & 1511 \\
\hline & & $20.5^{\#}$ & 0.379 & 0.370 & 0.364 & 0.355 & 0.340 & 0.101 & 0.096 & 0.025 & 1489 \\
\hline & $30-40$ & 458.0 & 0.441 & 0.437 & 0.415 & 0.368 & 0.295 & 0.111 & 0.108 & 0.033 & 1413 \\
\hline & & 846.7 & 0.443 & 0.429 & 0.413 & 0.376 & 0.321 & 0.135 & 0.146 & 0.042 & 1421 \\
\hline & $75-85$ & 104.9 & 0.361 & 0.343 & 0.326 & 0.262 & 0.160 & 0.018 & 0.034 & 0.005 & 1585 \\
\hline & & 198.3 & 0.316 & 0.308 & 0.302 & 0.231 & 0.121 & 0.021 & 0.039 & 0.006 & 1673 \\
\hline \multirow[t]{2}{*}{ Lichte klei, Ik } & $2-12$ & 1.4 & 0.390 & 0.375 & 0.371 & 0.349 & 0.320 & 0.193 & 0.209 & 0.027 & 1559 \\
\hline & & 18.8 & 0.398 & 0.391 & 0.384 & 0.340 & 0.314 & 0.198 & 0.216 & 0.028 & 1537 \\
\hline \multirow[t]{2}{*}{ Zware klei, zk } & $13-23$ & 69.4 & 0.547 & 0.537 & 0.521 & 0.511 & 0.503 & 0.346 & 0.318 & 0.064 & 1208 \\
\hline & & 151.6 & 0.552 & 0.545 & 0.532 & 0.519 & 0.512 & 0.391 & 0.329 & 0.068 & 1209 \\
\hline \multirow[t]{2}{*}{ Zand + $5 \mathrm{lk}$} & $3-13$ & 4.9 & n.b. & n.b. & n.b. & n.b. & n.b. & 0.108 & 0.112 & 0.024 & n.b. \\
\hline & & 8.0 & n.b. & n.b. & n.b. & n.b. & n.b. & 0.140 & 0.244 & 0.024 & n.b. \\
\hline \multirow[t]{2}{*}{ Zand + $10 \mathrm{lk}$} & $3-13$ & 18.8 & n.b. & n.b. & n.b. & n.b. & n.b. & 0.148 & 0.128 & 0.030 & n.b. \\
\hline & & 22.4 & n.b. & n.b. & n.b. & n.b. & n.b. & 0.171 & 0.160 & 0.030 & n.b. \\
\hline \multirow[t]{2}{*}{ Zand + 5 zk } & $3-13$ & 7.1 & n.b. & n.b. & n.b. & n.b. & n.b. & 0.114 & 0.115 & 0.029 & n.b. \\
\hline & & 8.0 & n.b. & n.b. & n.b. & n.b. & n.b. & 0.115 & 0.119 & 0.030 & n.b. \\
\hline \multirow[t]{2}{*}{ Zand $+10 \mathrm{zk}$} & $3-13$ & 10.4 & n.b. & n.b. & n.b. & n.b. & n.b. & 0.088 & 0.116 & 0.028 & n.b. \\
\hline & & $30.0^{\#}$ & n.b. & n.b. & n.b. & n.b. & n.b. & 0.116 & 0.119 & 0.032 & n.b. \\
\hline
\end{tabular}

\$:-70 geldt voor zware klei; @: dichtheid in $100 \mathrm{~cm}^{3}$ ringmonsters zandbakmethode; \#: wormgat zichtbaar aan bovenzijde; n.b.: niet bepaald 

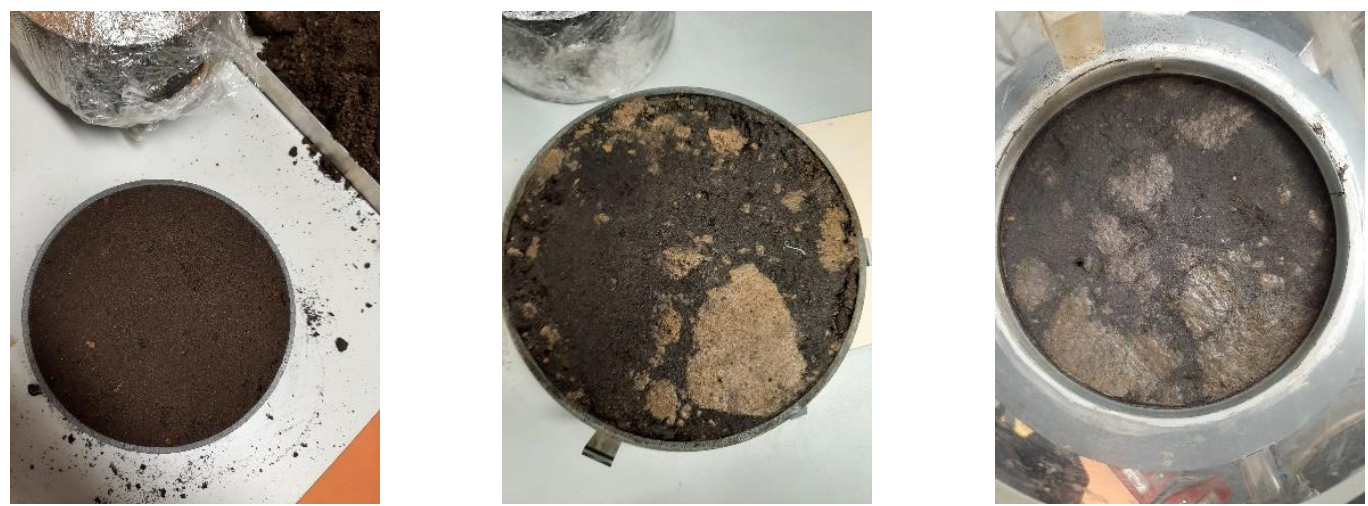

Figur 3.5 Bovenaanzichten van ongestoorde bodemmonsters waarin de doorlatendheid bij verzadiging is gemeten, voor zandmonsters en zandmonsters gemengd met lichte en zware klei (foto's van alle monsters zijn opgenomen in Bijlage 3).

\subsection{Simulaties}

De met SWAP-WOFOST gesimuleerde drogestofproductie van mais voor de vijf situaties/behandelingen is weergegeven in Figuur 3.6. Er zijn kleine verschillen tussen de behandelingen. Deze zijn het gevolg van verschillen in transpiratiereductie (primair door droogtestress). Over het algemeen geldt dat de situatie met $10 \mathrm{~cm}$ zware klei niet tot een hogere drogestofproductie leidt. De andere drie behandelingen laten jaren zien met een iets lagere en andere jaren met een iets hogere drogestofproductie.

De behandeling met $10 \mathrm{~cm}$ lichte klei toegediend aan zand laat vaak iets hogere producties zien dan de referentiesituatie. In paragraaf 4.3 werd getoond dat voor deze behandeling de (statische)

waterbeschikbaarheid kleiner was dan voor zand, maar ook dat de (stationaire) kritieke flux juist hoger was. Blijkbaar is het netto-effect dat er toch minder transpiratiereductie en dus iets meer gewasproductie wordt gesimuleerd voor deze behandeling ten opzichte van die van zand. Transpiratiereductie is het gevolg van het complexe samenspel tussen waterretentie- en doorlatendheidskarakteristieken in combinatie met de randvoorwaarden. Dat zal bepalen welke drukhoogtes er in de wortelzone voorkomen op basis waarvan al dan niet transpiratiereductie wordt vastgesteld.

Voor 2019 en 2020 is de gesimuleerde drogestofproductie voor de klei-in-zandbehandelingen gemiddeld iets hoger dan in de referentiesituatie en dit komt overeen met de waarnemingen van gemeten drogestofproductie (Luuk Gollenbeek, persoonlijke communicatie). De gemeten verschillen in producties waren over het algemeen niet significant.

De gesimuleerde drogestofproductie voor de klei-in-zandsituaties geven gemiddeld iets hogere drogestofopbrengsten. Het ligt voor de hand te veronderstellen dat dit betekent dat er minder droogtestress heeft plaatsgevonden. De verklaring is echter iets genuanceerder. Er blijkt een verschuiving op te treden in de verhouding droogteschade-natschade, maar ook de momenten waarop droogte- of natschade wordt ondervonden, verschilt voor de vijf situaties. We illustreren dit voor het jaar 1994. In Figuur 3.7 zien we dat voor de referentiesituatie de verhouding droogteschade-natschade ongeveer $50-50 \%$ was, maar voor de zand-in-kleisituaties zien we die verhouding veranderen: er treedt minder zuurstofstress op en relatief meer droogtestress. Voor de referentiesituatie en voor de situatie zand $+10 \mathrm{~cm}$ lichte klei zijn de drogestofproductie en de transpiratiereductie als gevolg van ofwel droogtestress ofwel zuurstofstress tijdens het groeiseizoen weergegeven in Figuur 3.8. Daaruit volgt dat voor de referentiesituatie (zand) er al vroeg in het groeiseizoen natschade wordt ondervonden. Het gewas loopt dus al vroeg in het seizoen een groeiachterstand op en dat kan niet meer worden gecompenseerd. De totale drogestofproductie valt daardoor lager uit dan voor de klei-in-zandsituatie, ondanks het feit dat voor deze klei-in-zandsituatie later in 
het groeiseizoen een piek in de droogtestress wordt waargenomen die groter is dan de piek voor de referentiessituatie.

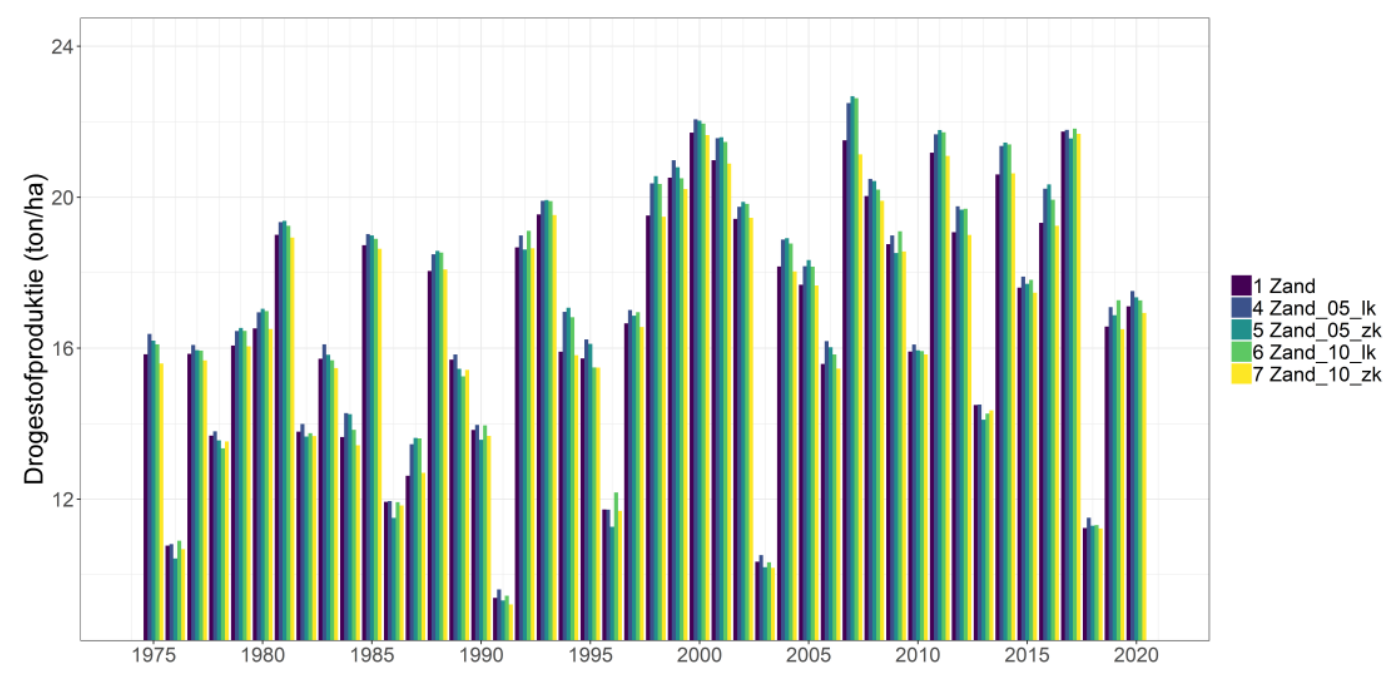

Figuur 3.6 Gesimuleerde drogestofproductie voor mais voor de vijf behandelingen. NB De $y$-as begint bij 9 t ha-1.

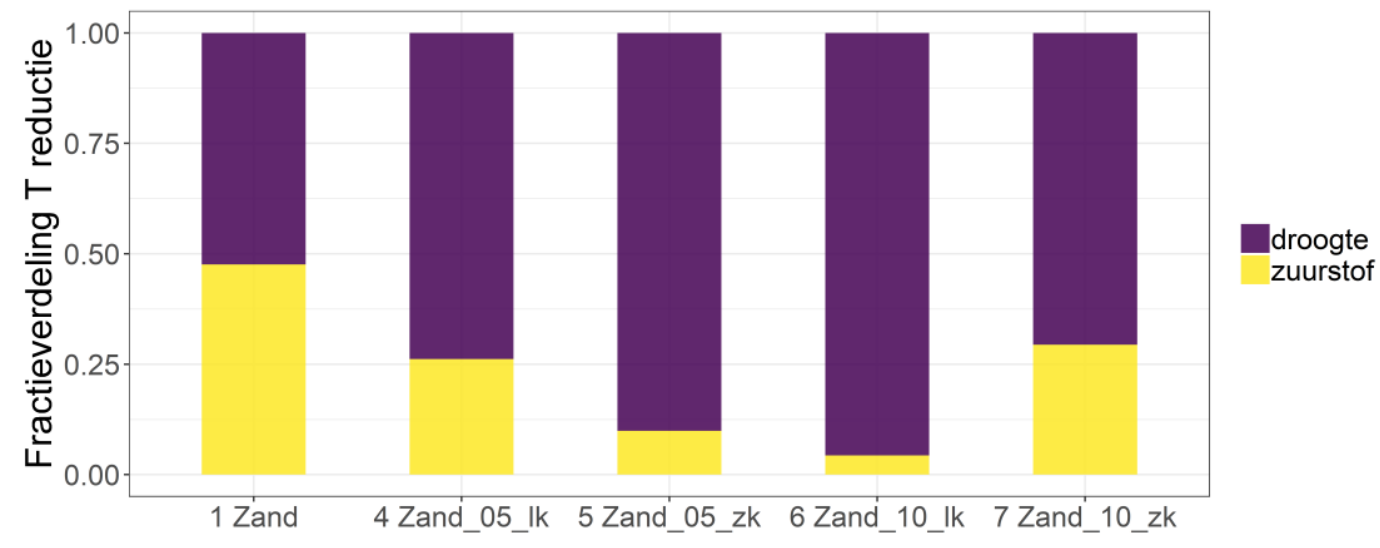

Figuur 3.7 De relatieve verdeling van de transpiratiereductie over aandeel droogtestress en aandeel zuurstofstress voor de vijf situaties in het jaar 1994.
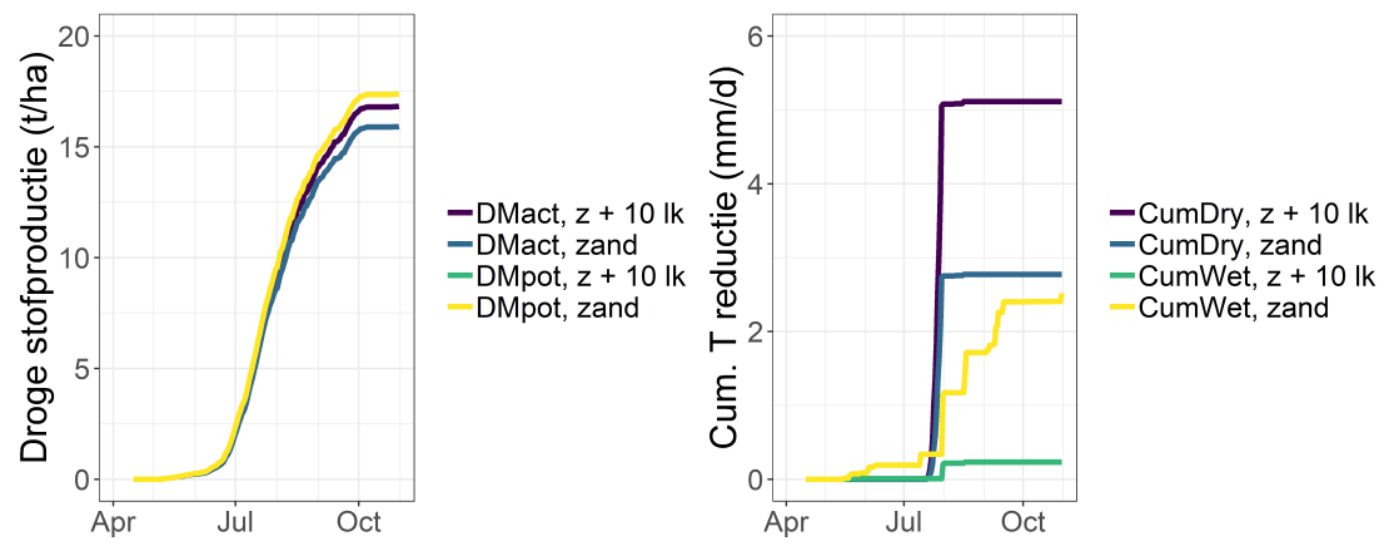

Figuur 3.8 Gesimuleerde drogestofproductie (links) en cumulatieve reductie in transpiratie, uitgesplitst in droogtestress (dry) en zuurstofstress (wet) (rechts) voor de referentiesituatie (zand) en de situatie zand met $10 \mathrm{~cm}$ lichte klei $(z+10 \mathrm{lk})$. NB DMpot is voor beide situaties identiek. 


\section{Bevindingen}

Voor zover bekend, zijn in Nederland niet eerder waterretentie- en doorlatendheidskarakteristieken gemeten in klei-in-zandbodemmonsters. In dit rapport worden de eerste resultaten van dergelijke metingen vermeld. De resultaten zijn nog niet geschikt om definitieve conclusies te trekken. Als reden hiertoe wordt gesteld dat i) het slechts een beperkt aantal monsters betreft, en ii) dat de monsters zijn genomen in een perceel waarin de klei niet mooi homogeen verdeeld in de bovenlaag was vermengd. De bevindingen luiden (puntsgewijs):

- De waterretentie- en doorlatendheidskarakteristieken van zand waaraan 5 of $10 \mathrm{~cm}$ lichte of zware klei is toegediend, verschuiven ten opzichte van die van zand in de richting van de karakteristieken van de lichte dan wel zware klei.

- Over het algemeen is de (statische) beschikbare hoeveelheid water in de laag 0-30 cm, berekend uit de waterretentiekarakteristiek, voor de klei-in-zandmonsters vergelijkbaar met die van zand. Voor de klei-inzandprofielen geldt over het algemeen dat de (stationaire) capillaire aanvulling vanuit de ondergrond, berekend uit de doorlatendheidskarakteristieken, wat groter kan zijn.

- Simulaties van de drogestofopbrengst van mais voor de jaren 1975-2020 laten zien dat er kleine verschillen zijn voor de klei-in-zandprofielen ten opzichte van de zand-uitgangssituatie. Gemiddeld over alle jaren zijn deze iets hoger. Dat komt overeen met de in het veld gemeten opbrengsten voor 2019 en 2020, waarin iets hogere - maar niet-significante verschillende - opbrengsten werden gemeten.

Het ligt voor de hand om deze studie te herhalen voor een perceel waarin de klei meer verkruimeld en homogener is gemengd met het zand. Omdat wordt voorzien dat de toediening van klei aan zand altijd via oppervlakkige toediening gevolgd door mengen via grondbewerking zal plaatsvinden, zal een perfecte menging nooit het gevolg zijn. Aan de andere kant: het meten van de waterretentie- en doorlatendheidskarakteristieken van ideaal gemengde klei-in-zand-monsters geeft wel een goed beeld van wat er ideaal bereikt zou kunnen worden. Uiteraard zouden dan in zo'n nieuwe proef ook aanvullende gewasregistraties (opbrengsten en eventueel aanvullende metingen over bijv. bewortelingsdiepte) moeten plaatsvinden.

Uit de exploratieve SWAP-WOFOST-simulatieberekeningen kwam naar voren dat de verhouding droogtestress-zuurstofstress verschillend was tussen de vijf behandelingen. Deze stressfactoren verschilden niet alleen in absolute zin, maar ook in de momenten waarop ze werden gesimuleerd. Dit vraagt om nadere analyse waarom deze verschillen precies optreden, waarbij er onder meer ook aandacht moet zijn voor de ontwikkeling van de bewortelingsdiepte en wortelverdeling. 


\section{Literatuur}

Alakayleh, Z., T. Prabhakar Clement and X. Fang. 2018. Understanding the changes in hydraulic conductivity values of coarse- and fine-grained porous media mixtures. Water (Switzerland) 10(3).

Bakker, G., M. Heinen, H.P.A. Gooren, W.J.M. de Groot, P.D. Peters. 2020. Hydrofysische gegevens van de bodem in de Basisregistratie Ondergrond (BRO) en het Bodemkundig Informatie Systeem (BIS); Update 2019. WOt-technical report 186, Wettelijke Onderzoekstaken Natuur \& Milieu, Wageningen.

Benkhelifa, M., M. Belkhodja, Y. Daoud and D. Tessier. 2008. Effects of Maghnian bentonite on physical properties of sandy soils under semi-arid mediterranean climate. Pakistan Journal of Biological Sciences 11(1): 17-25.

Betti, G., C. D. Grant, R. S. Murray and G. J. Churchman. 2016. Size of subsoil clods affects soil-water availability in sand-clay mixtures. Soil Research 54(3): 276-290.

Brown, K. W., G. B. Evans and J. C. Thomas. 1985. Increased soil water retention by mixing horizons of shallow sandy soils. Soil Science 139: 118-121.

Gill, J.S., J. Tisdall, Sukartono, I.G.M. Kusnarta and B.M. McKenzie. 2004. Physical properties of a clay loam soil mixed with sand. In 'SuperSoil 2004: 3rd Australian \& New Zealand Soils Conference'. 5-9 December 2004. (The Regional Institute Ltd: Gosford, NSW) Available at: www.regional.org.au/au/asssi/supersoil2004/s14/poster/1585_gillj.htm

Halilat, M. T. and D. Tessier. 2006. Improvement of sandy material water content by addition of bentonite. Cahiers Agricultures 15(4): 347-353.

Harper, R.J. and R.J. Gilkes. 2004. The effects of clay and sand additions on the strength of sandy topsoils. Australian Journal of Soil Research 42: 39-44.

Heinen, M., G. Bakker, H. Wösten, 2020. Waterretentie- en doorlatendheidskarakteristieken van boven- en ondergronden in Nederland: de Staringreeks; update 2018. Rapport 2978, Wageningen Environmental Research, Wageningen.

Heinen, M., F. Brouwer, K. Teuling, D. Walvoort, 2021. BOFEK 2020 - Bodemfysische schematisatie van Nederland. Update bodemfysische eenhedenkaart. Rapport 3056, Wageningen, Wageningen Environmental Research.

Kroes, J.G., J.C. van Dam, R.P. Bartholomeus, P. Groenendijk, M. Heinen, R.F.A. Hendriks, H.M. Mulder, I. Supit, \& P.E.V. van Walsum. 2017. SWAP version 4. Theory description and user manual. Report 2780, Wageningen Environmental Research, Wageningen, the Netherlands.

Mualem, Y. 1976. A new model for predicting the hydraulic conductivity of unsaturated porous media. Water Resources Research, 12: 513-522.

Van Genuchten, M.Th., 1980. A closed-form equation for predicting the hydraulic conductivity of unsaturated soils. Soil Science Society of America Journal 44(3): 892-898. 


\section{Bijlage 1 Quickscan literatuur}

Via SCOPUS zijn via de zoekopdracht

TITLE-ABS-KEY (("water retention" OR "hydraulic conductivity") AND ("clay sand mixture" OR "sand clay mixture")) AND (LIMIT-TO (SUBJAREA, "AGRI"))

in totaal 23 referenties verkregen. Op basis van de titel en abstract zijn hieruit vier referenties gekozen. Halilat \& Tessier (2006) mengden bentoniet in Algerijnse Sahara zand. Zij concludeerden dat bij minder dan $12 \%$ klei toevoegen dit geen invloed had op het ontstaan van te natte situaties en op zwellen. Benkhelifa et al. (2008) concludeerden dat het toevoegen van bentoniet aan (Algerijns Sahara)zand significante invloed had op de fysische eigenschappen van de mengsels. De doorlatendheid bij verzadiging ( $\left.K_{\text {sat }}\right)$ van bentoniet was ongeveer een factor 100 lager dan die van het zand. Mengsels van $10 \%$ en $50 \%$ betoniet in zand verlaagde $K_{\text {sat }}$ met een factor van respectievelijk 4.5 en 45. In een uitgebreide laboratoriumstudie bepaalden Betti et al. (2016) de effecten van het bijmengen van klei met verschillende gewichtsfracties $(10 \%, 20 \%$, $40 \%, 60 \%$ ) en verschillende aggregaatgroottes $(<2,6,20,45 \mathrm{~mm})$. Hierbij werd onder meer gekeken naar de effecten op waterretentie, waterbeschikbaarheid en doorlatendheid. Zij concludeerden dat de toevoeging van klei resulteert in een verlaging van $K_{\text {sat, }}$ een verandering van de vorm van de waterretentiekarakteristiek en dus in de waterbeschikbaarheid. Deze laatste wordt hoger bij een toenemend kleigehalte. Voor de behandelingen met grotere aggregaten klei werd een iets grotere toename in waterbeschikbaarheid gemeten dan in de behandelingen waarin de fijngemalen klei aan zand werd toegediend. Duidelijke effecten op waterbeschikbaarheid worden verkregen indien 10-20\% klei wordt toegevoegd; indien veel meer klei wordt toegediend (bijv. 40-60\%), kan dit weer een negatief effect hebben op waterbeschikbaarheid. Alakayleh et al. (2018) presenteerden een model om $K_{\text {sat }}$ af te leiden voor kunstmatig gemaakte zand-

bentonietmengsels (bijvoorbeeld voor gebruik als afdichtingsmaterialen). Zij geven echter aan dat dit model niet toepasbaar is op natuurlijke gronden en niet-geconditioneerde mengingen.

Betti et al. (2016) verwijzen naar eerdere studies van Brown et al. (1985), Gill et al. (2004) en Harper \& Gilkes (2004). Brown et al. (1985) concludeerden dat de toevoeging van klei leidt tot een toename in waterbeschikbaarheid en een afname in infiltratiecapaciteit. Gill et al. (2004) bestudeerden de invloed van zand mengen in kleigrond. Zij concludeerden dat de treksterkte afnam, dat de hydraulische eigenschappen verbeterden en dat de beworteling en groei verbeterden in de zand-kleimengsels ten opzichte van pure kleigrond. Harper \& Gilkes (2004) concludeerden dat de bodemsterkte van zandgronden toenam bij toename van de hoeveelheid klei die in de zandgrond werd gemengd. 


\section{Bijlage 2 Figuren dataverwerking verdampingsmethode}

In onderstaande figuren zijn de resultaten van de verwerking van de verdampingsmethode voor de achttien monsters weergegeven. Achtereenvolgens:

- Zand, laag 3-13 cm

- Lichte klei, laag 2-12 cm

- Zware klei, laag 2-12 cm

- Zand $+5 \mathrm{~cm}$ lichte klei, laag 3-13 cm

- Zand $+10 \mathrm{~cm}$ zware klei, laag 3-13 cm

- Zand $+5 \mathrm{~cm}$ lichte klei, laag 3-13 cm

- Zand $+10 \mathrm{~cm}$ zware klei, laag 3-13 cm

- Zand, laag 40-50 cm

- Zand, laag 75-85 cm

\section{Zand, laag 3-13 cm}
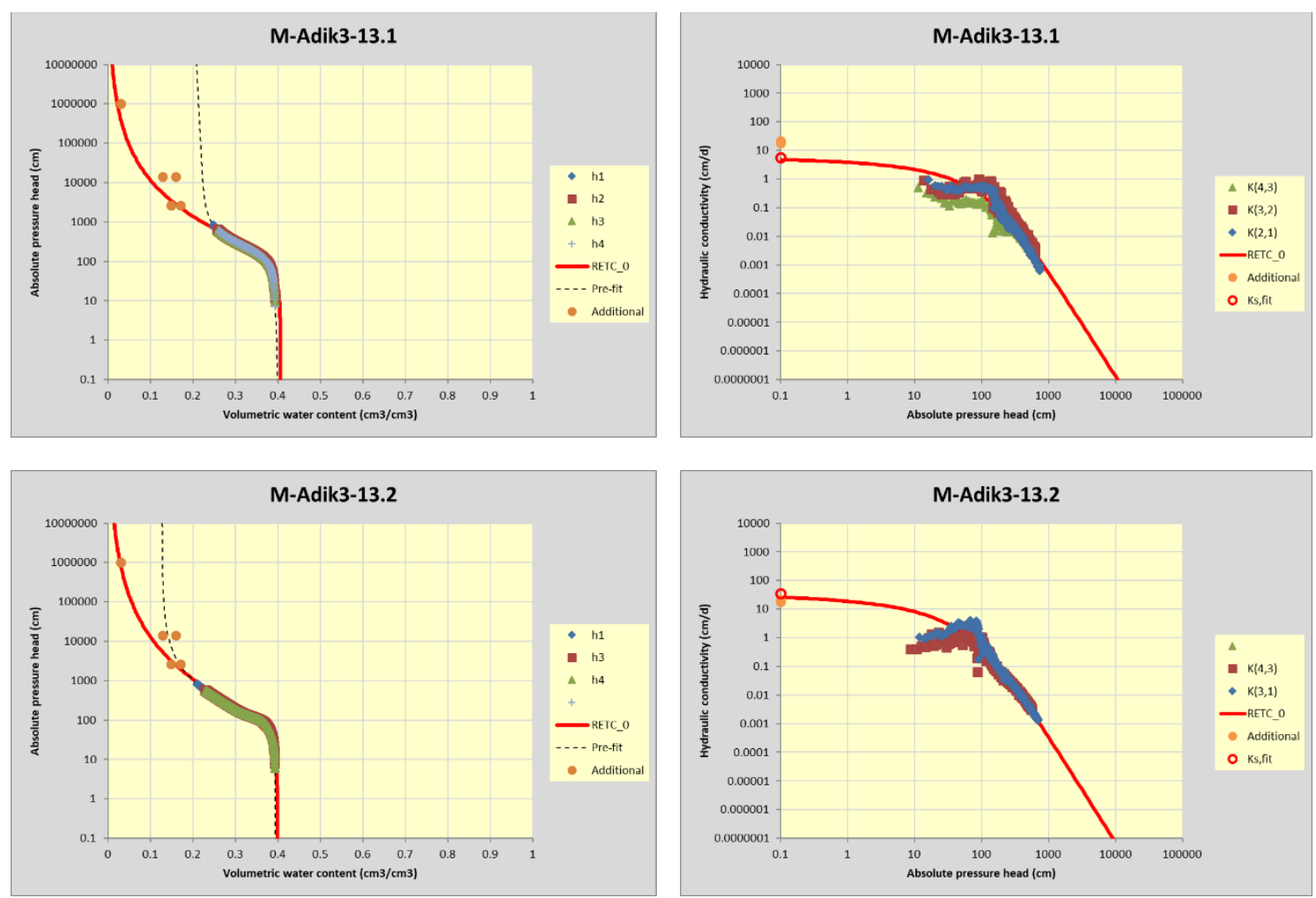


\section{Lichte klei, laag 2-12 cm}
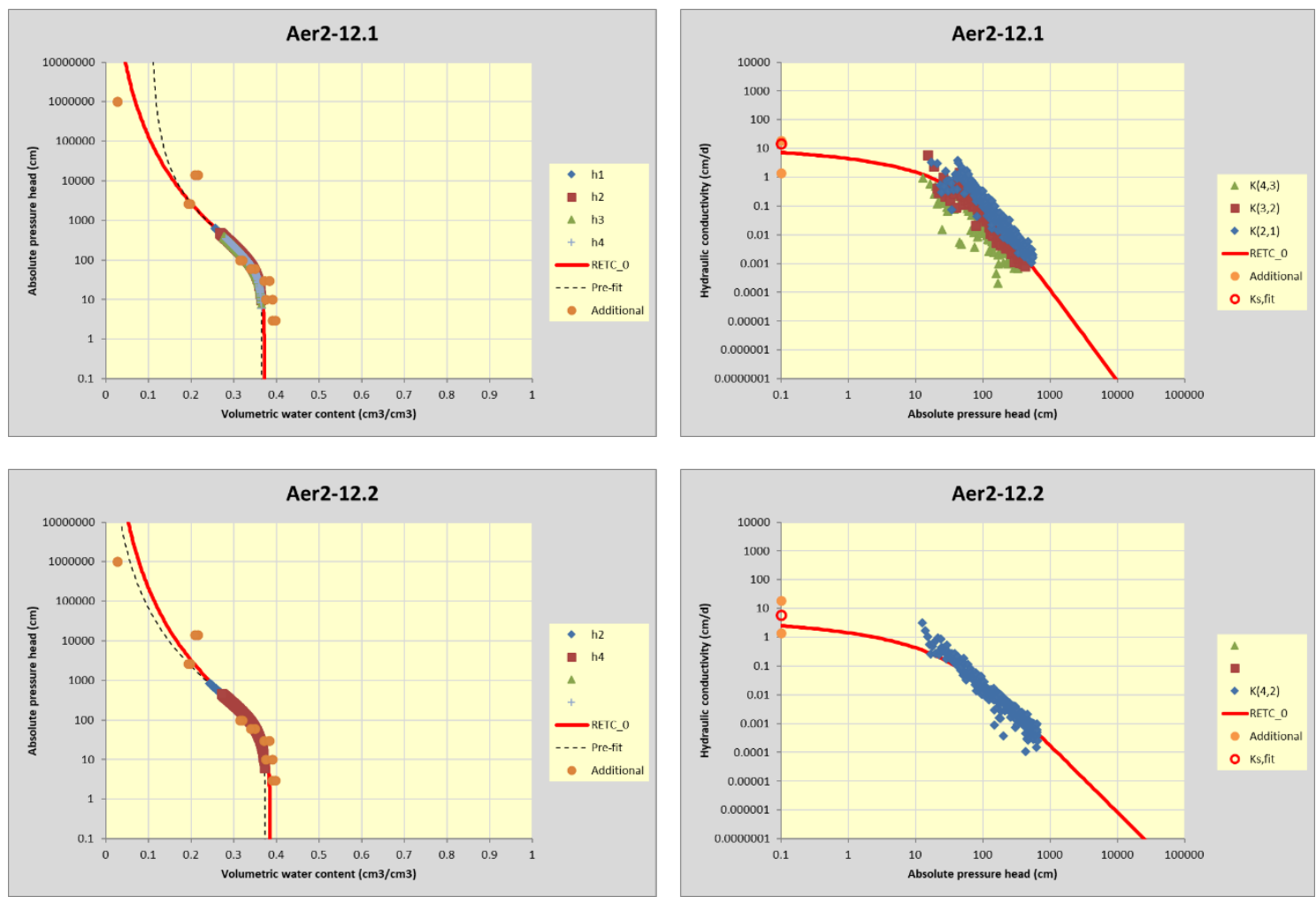

Zware klei, laag 2-12 cm
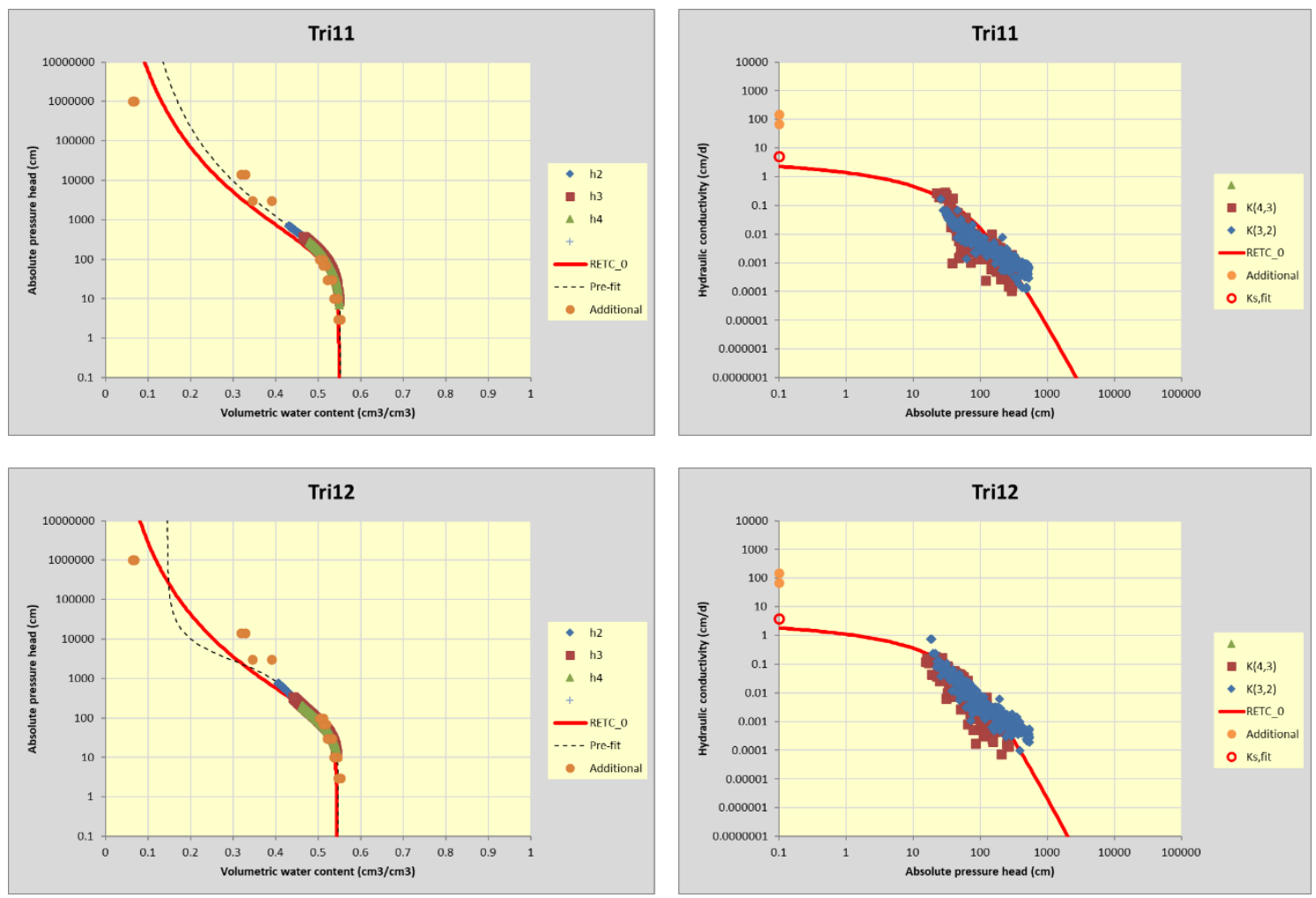
Zand + $5 \mathrm{~cm}$ lichte klei, laag 3-13 cm
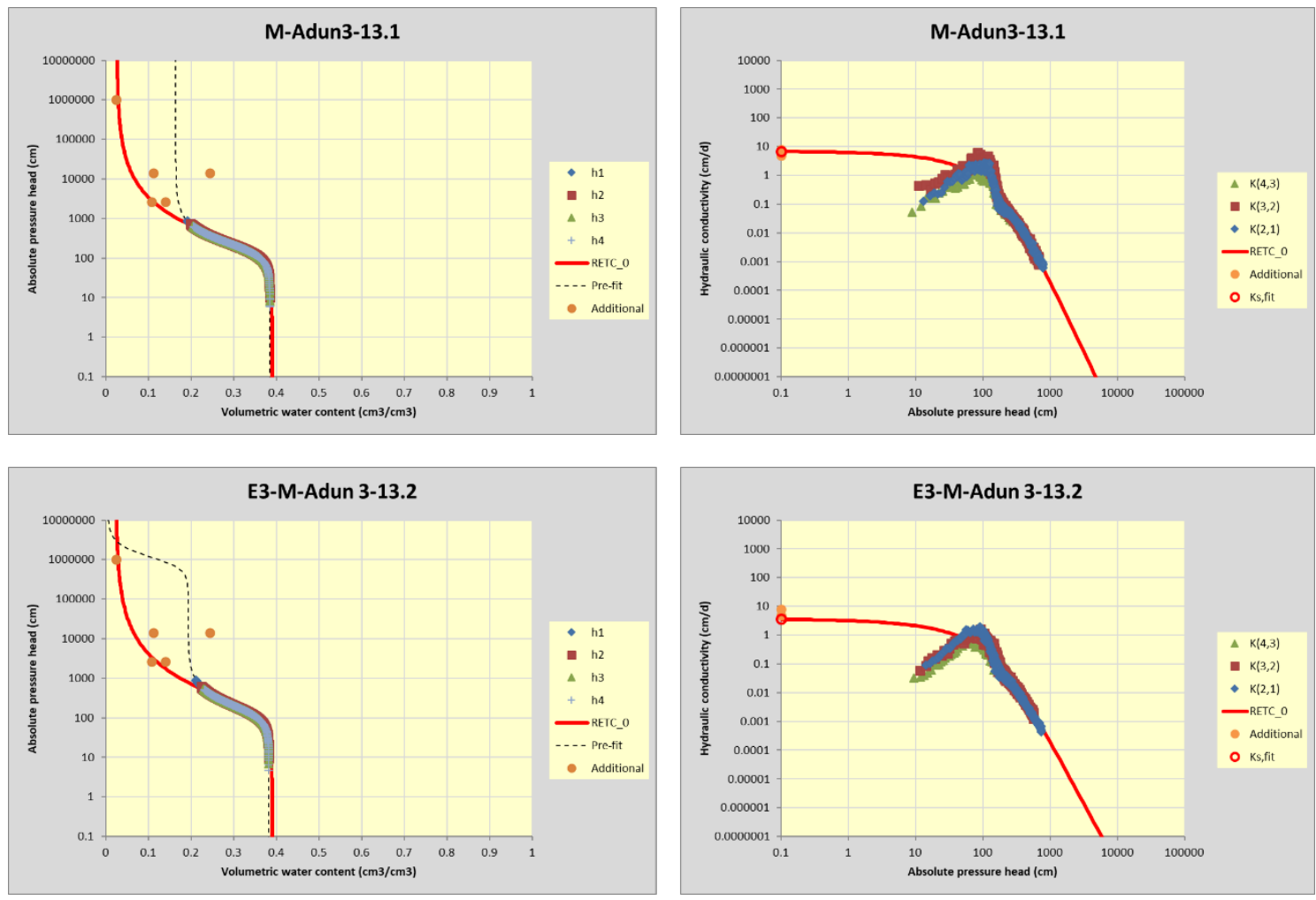

Zand + $5 \mathrm{~cm}$ zware klei, laag 3-13 cm
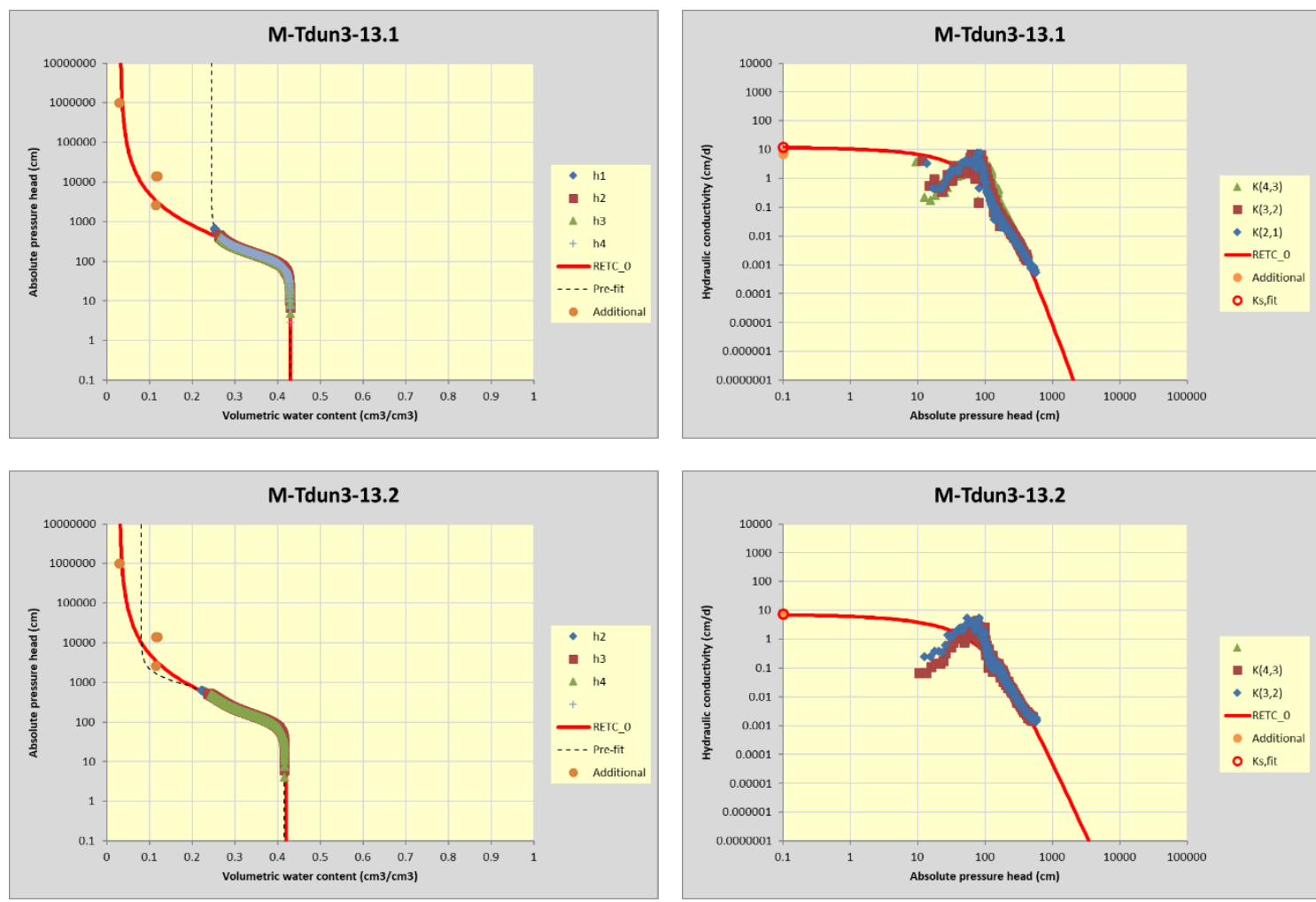
Zand + $10 \mathrm{~cm}$ lichte klei, laag 3-13 cm
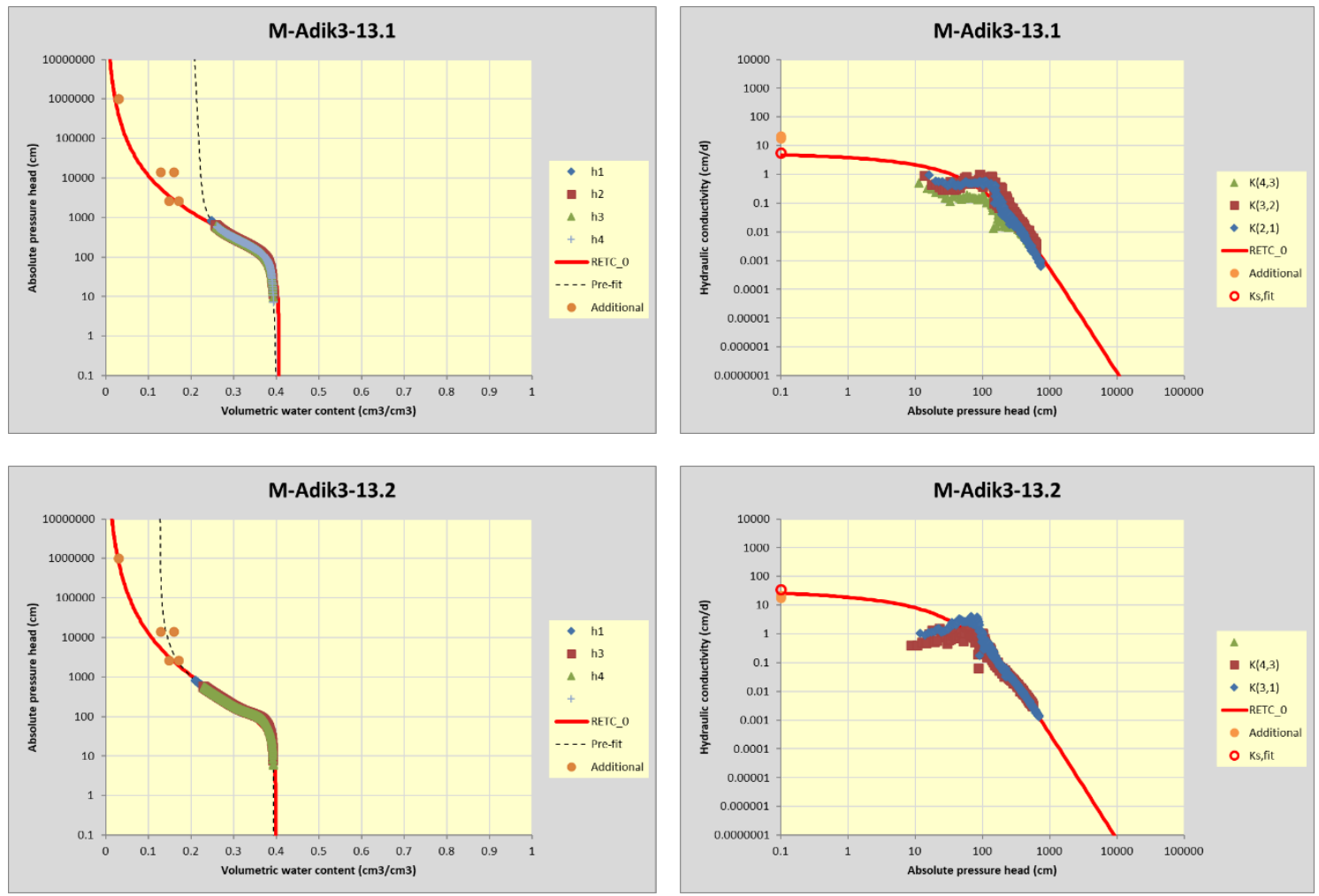

Zand + $10 \mathrm{~cm}$ zware klei, laag 3-13 cm
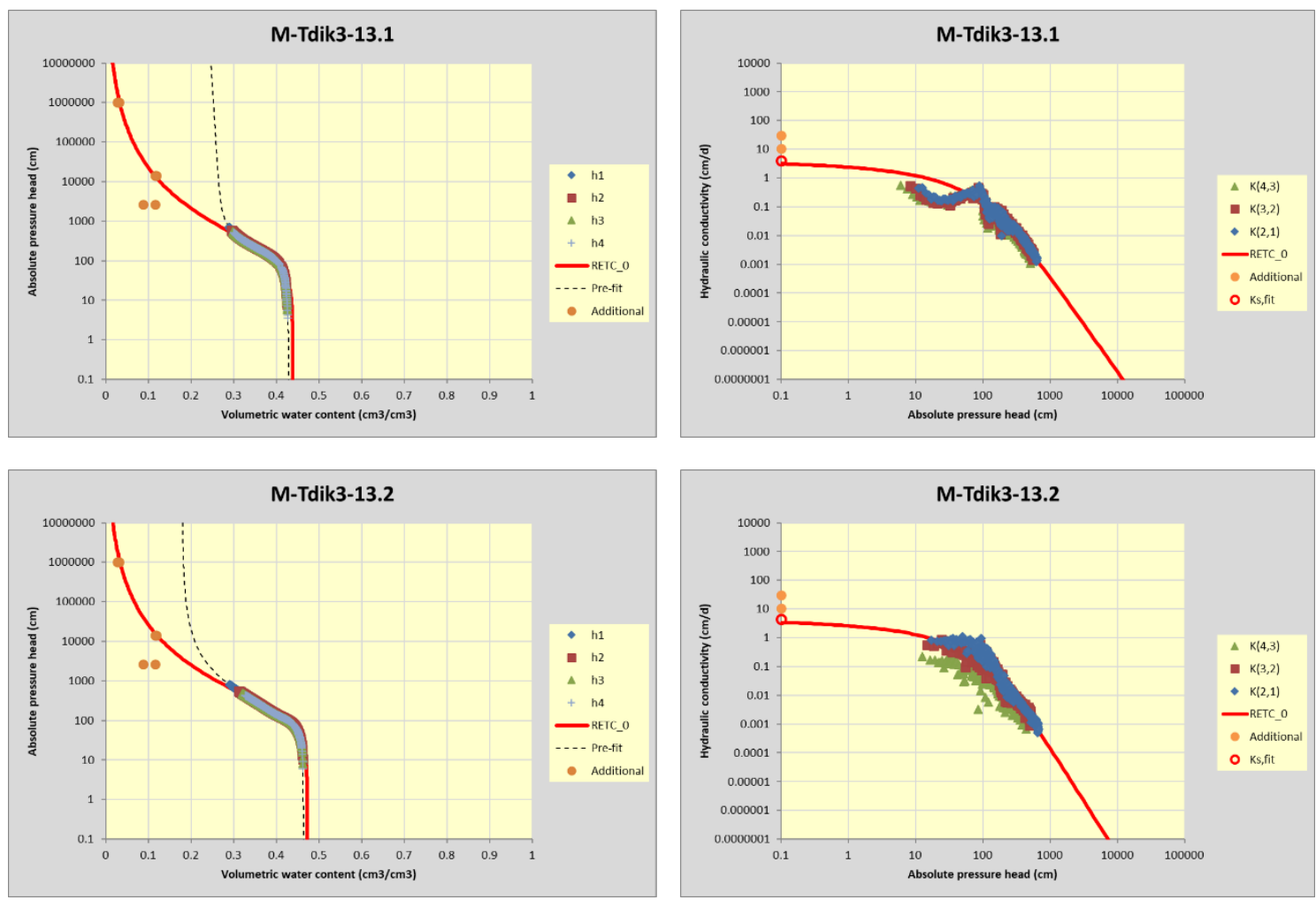
Zand, laag 40-50 cm
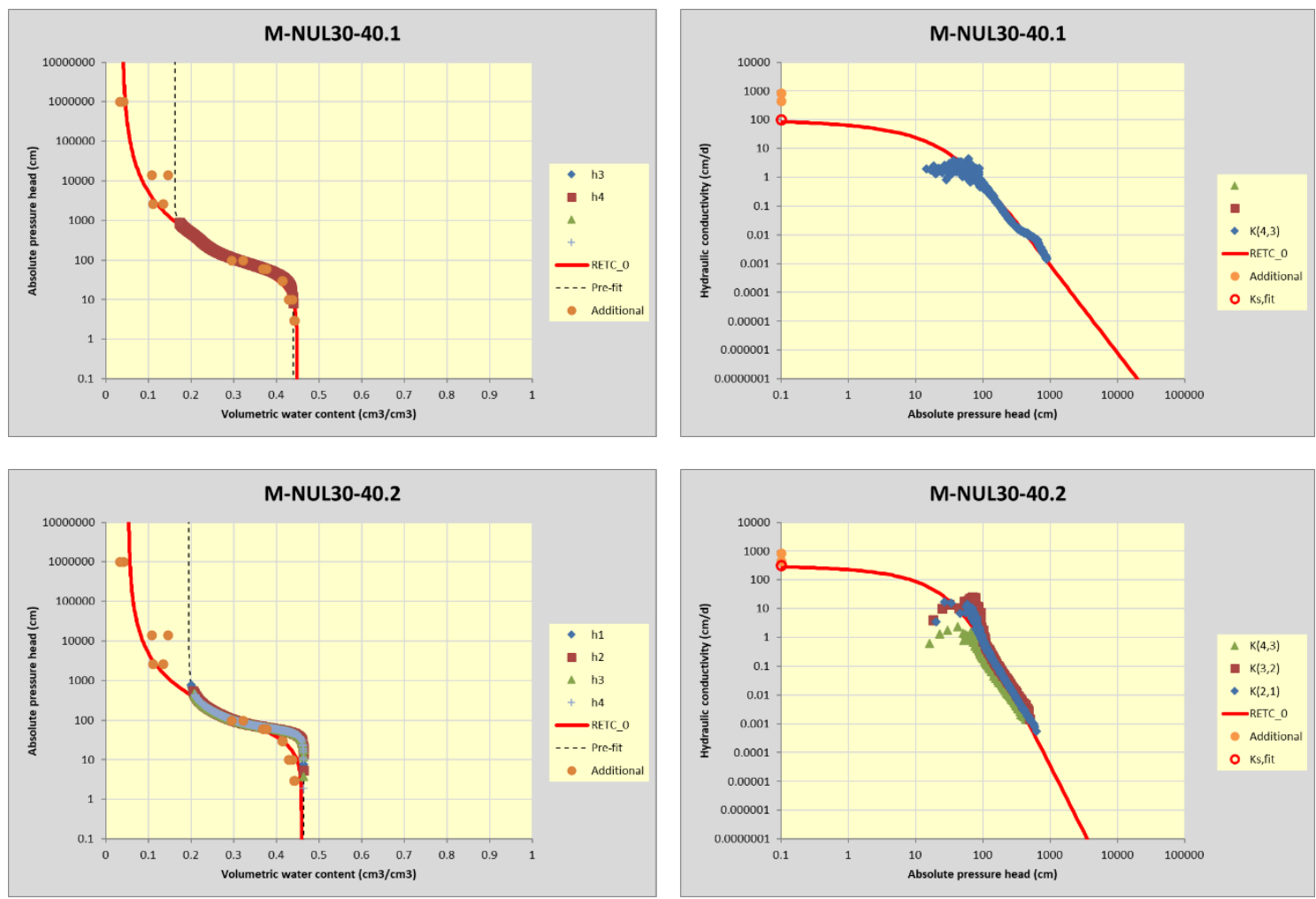

Zand, laag 75-85 cm
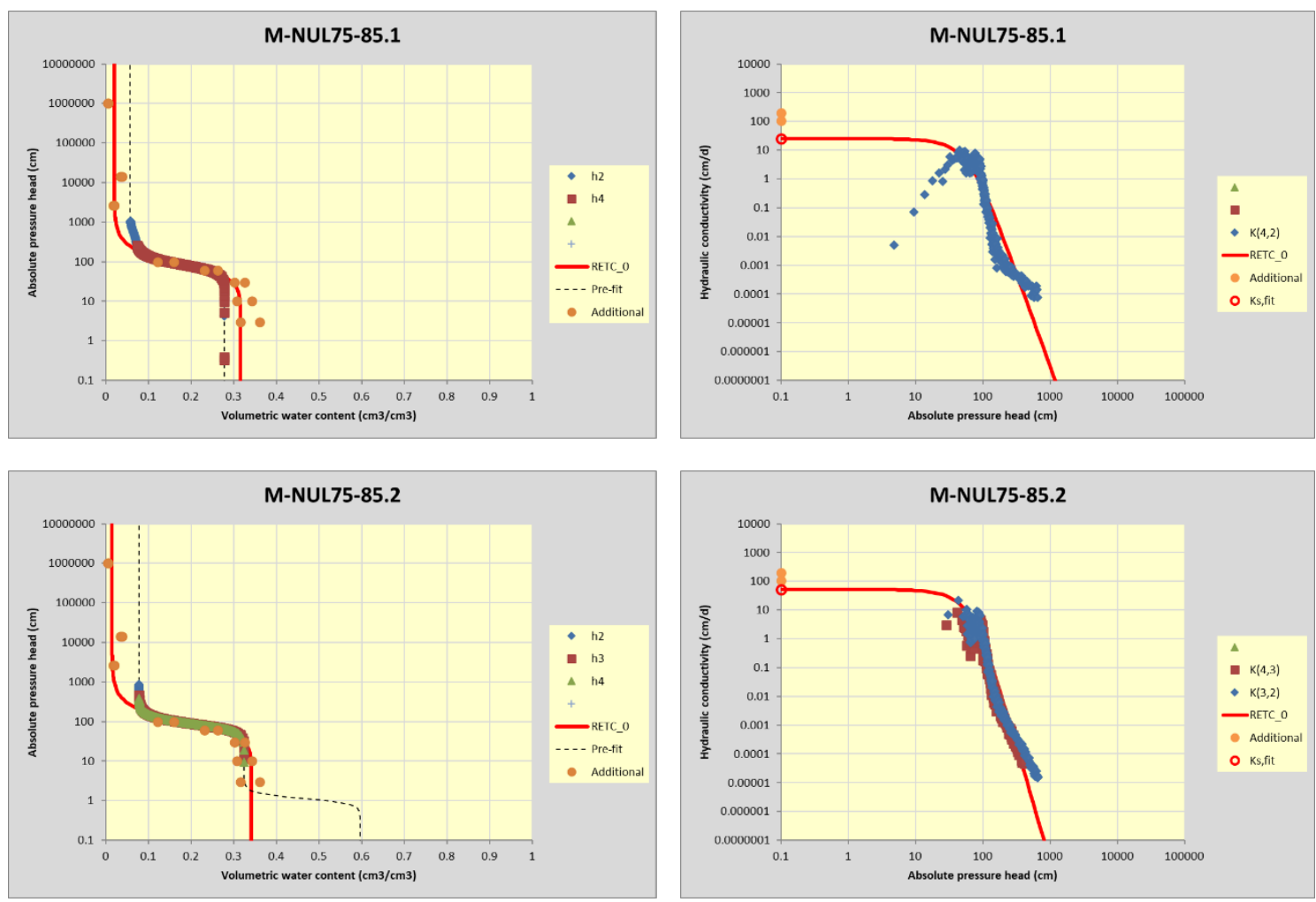


\section{Bijlage 3 Foto's monsters doorlatendheidsmetingen}

Monster 1 voor meting

Zand; $3-13 \mathrm{~cm}-\mathrm{mv}$

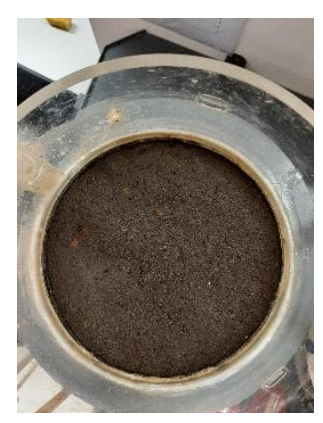

Zand; $30-40 \mathrm{~cm}-\mathrm{mv}$

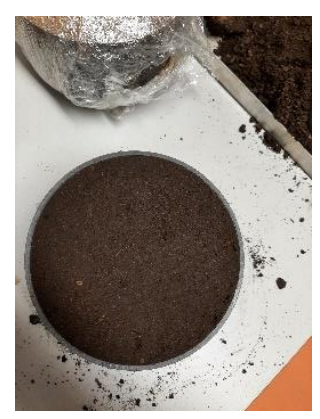

Zand; $75-85 \mathrm{~cm}-\mathrm{mv}$

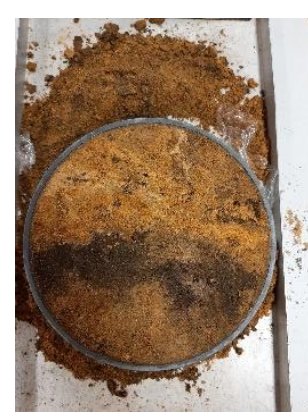

Zand $+5 l k$

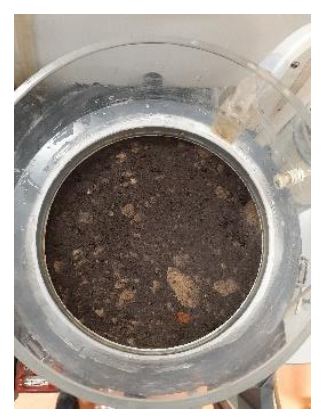

Monster 1 na meting
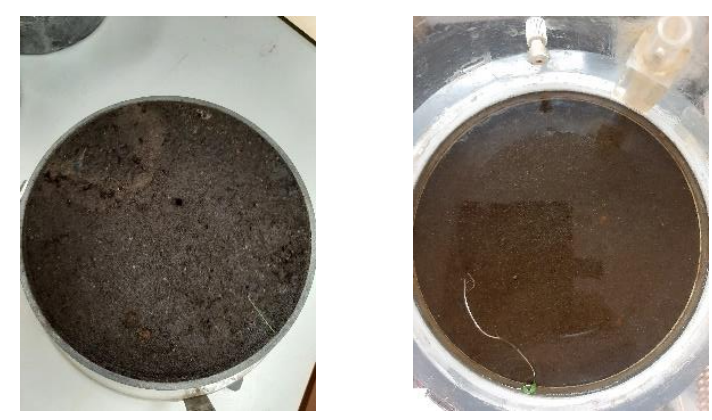

n.b.

n.b.

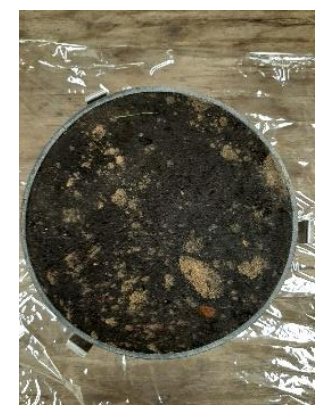

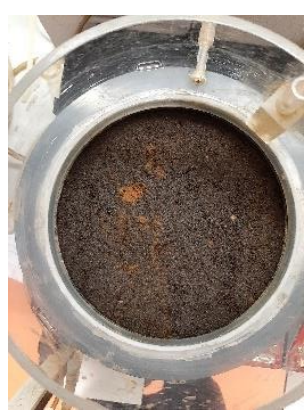

Monster 2 voor meting

Monster 2 na meting

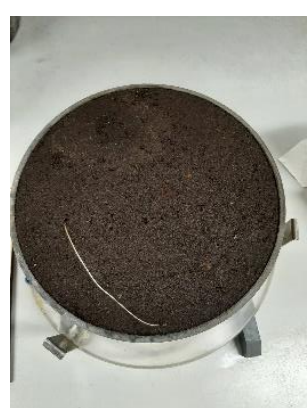

n.b.

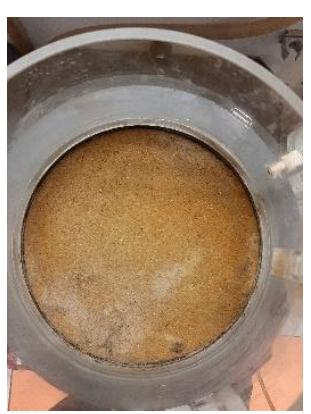

n.b.

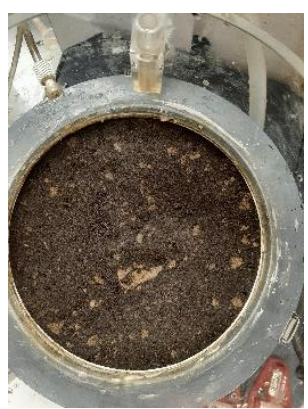

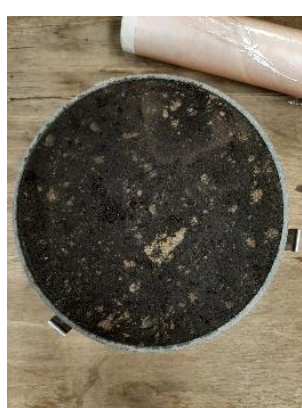




\section{Zand + $10 \mathrm{lk}$}
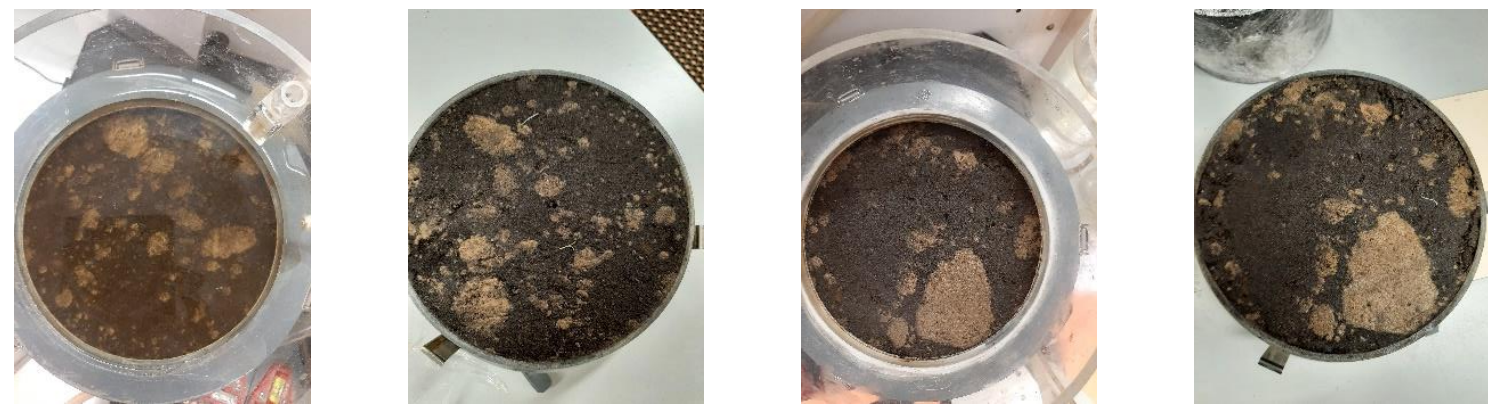

Zand + 5 zk
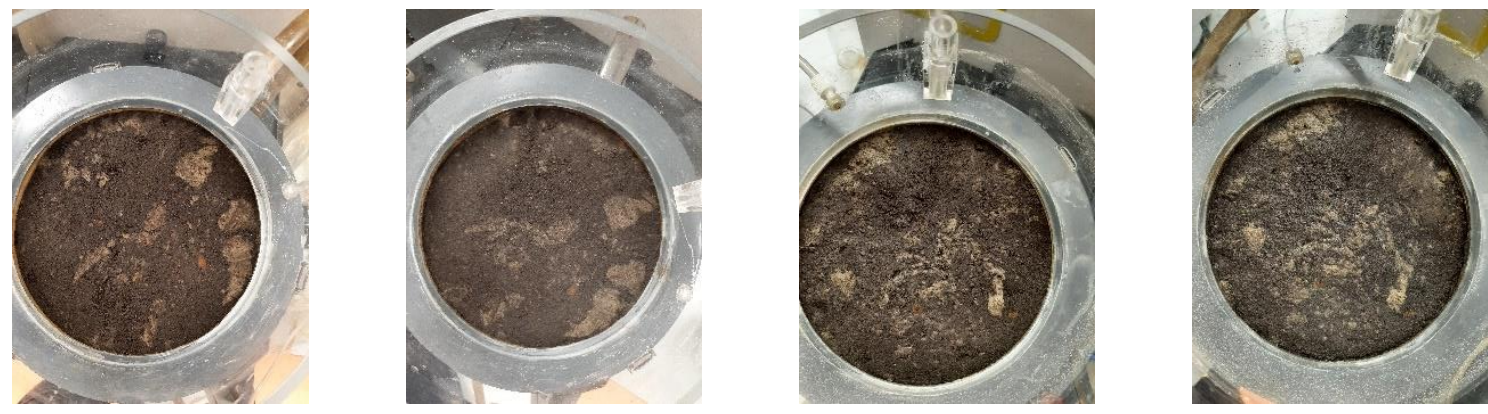

Zand + $10 z k$
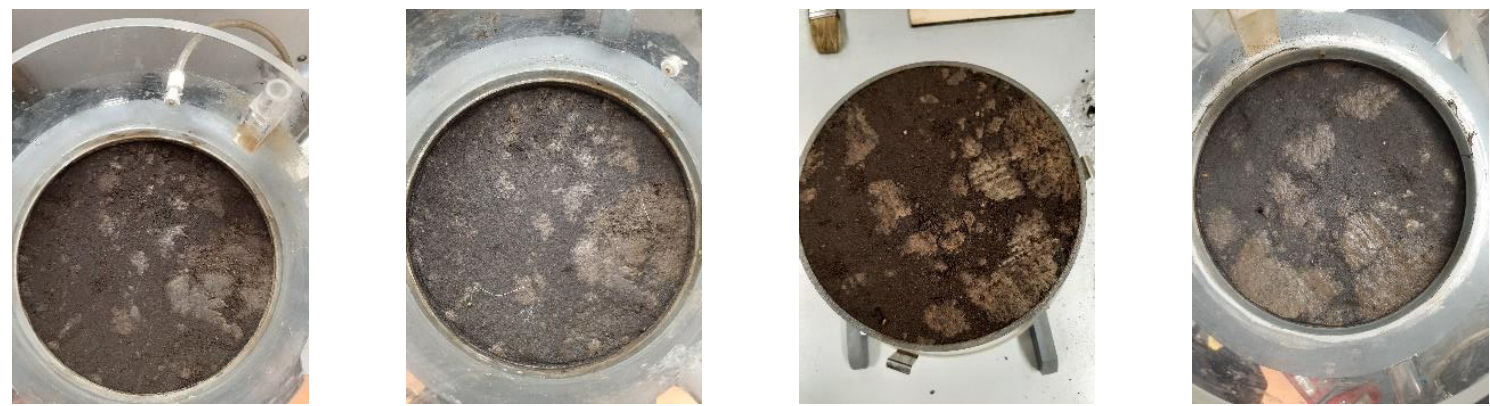

\section{Lichte klei}
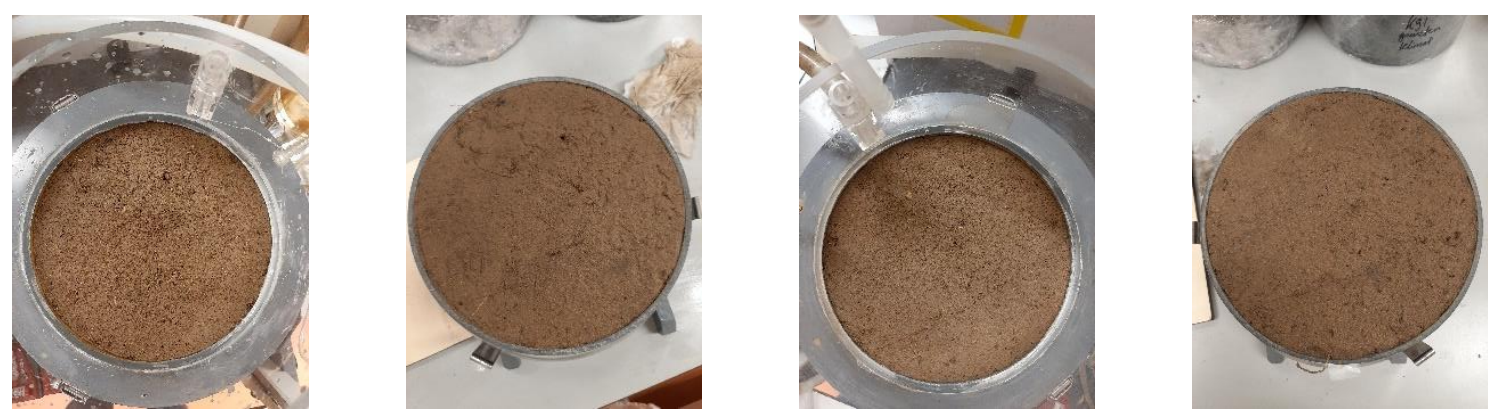

Zware klei

n.b.

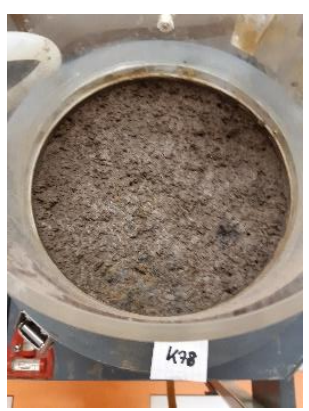

n.b.

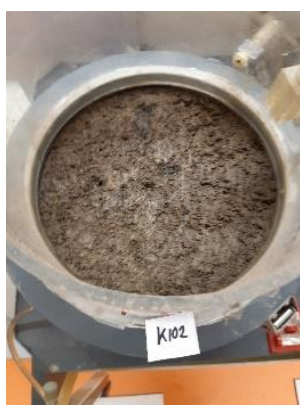


Wageningen Environmental Research Postbus 47

6700 AA Wageningen

T 0317480700

wur.nl/environmental-research

Wageningen Environmental Research

Rapport 3145

ISSN 1566-7197
De missie van Wageningen University \& Research is 'To explore the potential of nature to improve the quality of life'. Binnen Wageningen University \& Research bundelen Wageningen University en gespecialiseerde onderzoeksinstituten van Stichting Wageningen Research hun krachten om bij te dragen aan de oplossing van belangrijke vragen in het domein van gezonde voeding en leefomgeving. Met ongeveer 30 vestigingen, 6.800 medewerkers ( $6.000 \mathrm{fte}$ ) en 12.900 studenten behoort Wageningen University \& Research wereldwijd tot de aansprekende kennisinstellingen binnen haar domein. De integrale benadering van de vraagstukken en de samenwerking tussen verschillende disciplines vormen het hart van de unieke Wageningen aanpak. 



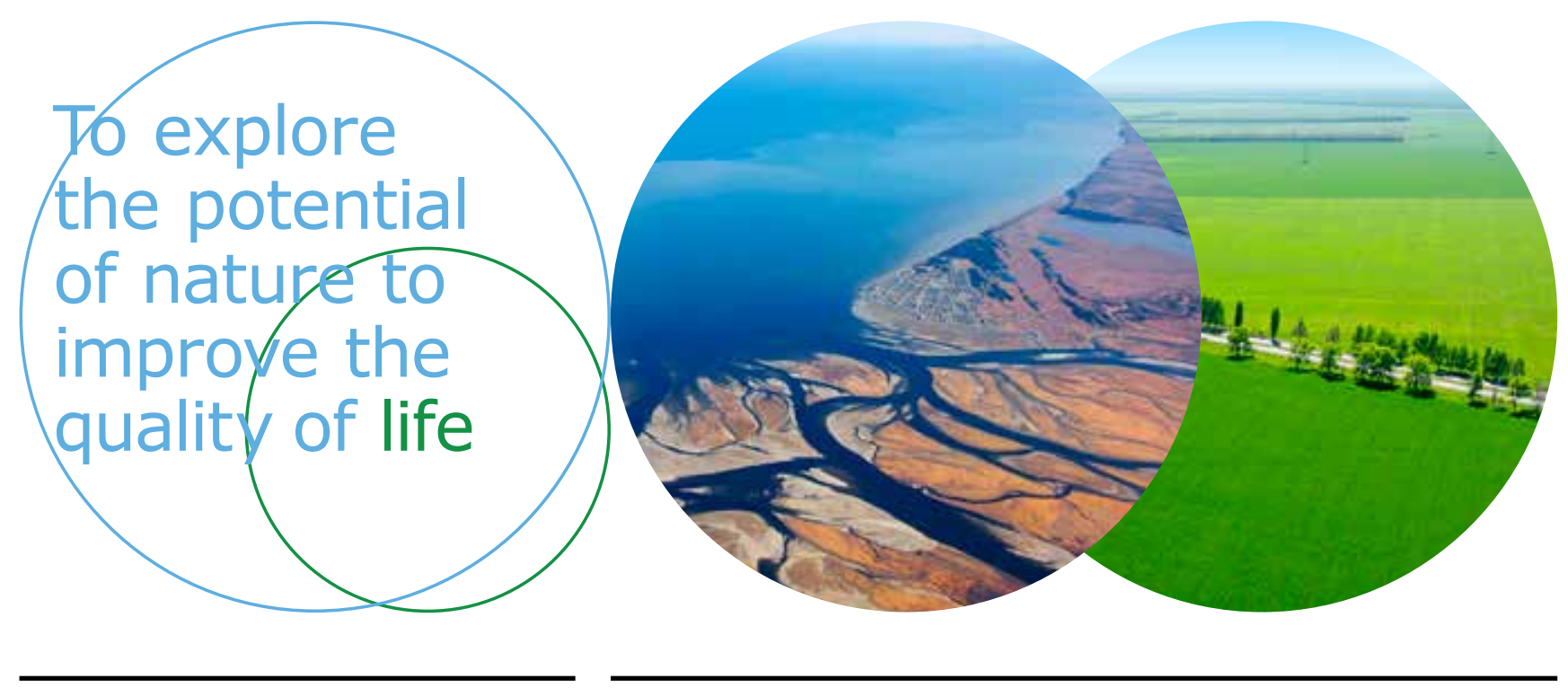

Wageningen Environmental Research Postbus 47

$6700 \mathrm{AB}$ Wageningen

T 0317480700

wur.nl/environmental-research

Rapport 3145

ISSN 1566-7197
De missie van Wageningen University \& Research is 'To explore the potential of nature to improve the quality of life'. Binnen Wageningen University \& Research bundelen Wageningen University en gespecialiseerde onderzoeksinstituten van Stichting Wageningen Research hun krachten om bij te dragen aan de oplossing van belangrijke vragen in het domein van gezonde voeding en leefomgeving. Met ongeveer 30 vestigingen, 6.800 medewerkers ( $6.000 \mathrm{fte}$ ) en 12.900 studenten behoort Wageningen University \& Research wereldwijd tot de aansprekende kennisinstellingen binnen haar domein. De integrale benadering van de vraagstukken en de samenwerking tussen verschillende disciplines vormen het hart van de unieke Wageningen aanpak. 